\title{
Paisajes y personajes del sur mexicano en la obra de Arthur Morelet: invitación a su lectura
}

\section{Landscapes and Characters of the South Mexican in the Work of Arthur Morelet: A Reading Invitation}

\author{
Mario HumberTo Ruz \\ Centro de Estudios Mayas, Instituto de Investigaciones Filológicas, \\ Universidad Nacional Autónoma de México. México
}

\begin{abstract}
Resumen: En la denominada "literatura de viajes", que da cuenta de las impresiones que nuestro país y sus habitantes suscitaron en visitantes extranjeros, el libro del naturalista francés Pierre Marie Arthur Morelet, Voyage dans L'Amérique Centrale, Lile de Cuba et le Yucatan (París, 1857), ocupa sin duda un lugar de honor dada la calidad de descripciones del paisaje, lo agudo de sus observaciones acerca de la situación socioeconómica del meridión nacional, sus valiosas reflexiones sobre la cultura maya (ancladas en su formación enciclopédica) y la excelencia de su pluma. El artículo es una invitación a su lectura dada su reciente edición íntegra en español.
\end{abstract}

Palabras clave: Arthur Morelet, literatura de viajes, sur de México, naturaleza, cultura maya.

AвSTRACT: In the genre designated "travel literature", which reflects the impressions that our country and its people raised in foreign visitors, the book by French naturalist Pierre Marie Arthur Morelet, Voyage dans L'Amerique Centrale, L'ile de Cuba et le Yucatan (Paris, 1857), certainly occupies a place of honor given the quality of his landscape descriptions, the sharpness of his observations on the socioeconomic situation of Southern Mexico, his significant reflections on culture (rooted in his encyclopedic training) and the excellence of his pen. This article is an invitation to read his work, in the light of its recent full publication in Spanish.

KEYwoRDs: Arthur Morelet, travel literature, Southern Mexico, nature, Maya culture. 
RECEPCIÓN: 30 de julio de 2019.

ACEPTACIÓN: 4 de septiembre de 2019.

DOI: https://doi.org/10.19130/iifl.ecm.55.2020.0007

En diciembre de 1846 desembarcó en La Habana Pierre-Marie-Arthur Morelet (Figura 1), nacido en 1809 en el castillo de Lays-sur-le Doubs, en la Borgoña francesa, quien destacaría en las Ciencias Naturales, en especial en el campo de la malacología. Viajero apasionado, antes de cumplir 40 años conocía la Italia continental e insular, Argelia, Inglaterra, Suiza, España y Portugal. Para su viaje al continente americano obtuvo de la Academia de Ciencias de Francia una comisión tendiente a proveer de ejemplares vegetales, animales y minerales al Museo de Ciencias Naturales de París. ${ }^{1}$ Tras dos meses de recorrer Cuba se dirigió a la península yucateca.

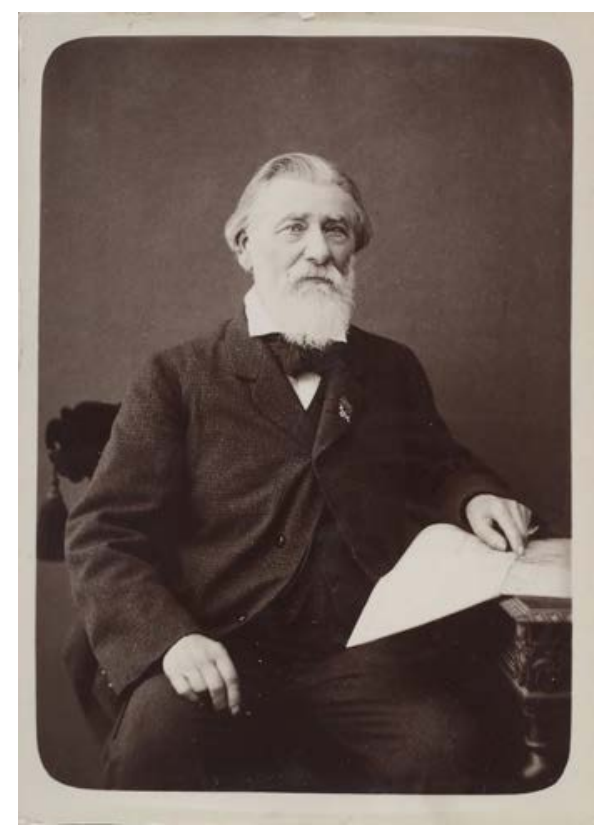

Figura 1. Retrato de A. Morelet

(Fuente: gallica.bnf.fr / Bibliothèque nationale de France).

Viajaba provisto de indicaciones más bien magras, pues los habaneros a quienes pidió referencias apenas si conocían la tierra firme más allá de los puntos donde practicaban el cabotaje, pero, eso sí, la imaginación de los isleños sembró "liberalmente" de peligros el camino del visitante, como recordaría en su libro

\footnotetext{
${ }^{1}$ Una reseña biográfica del personaje, debida a Arturo Taracena Arriola, consta en el ensayo "El mundo americano de Arthur Morelet" (Taracena, 2015).
} 
Voyage dans L'Amérique Centrale, Lile de Cuba et le Yucatán (Figura 2), publicado en París en 1857 por Gide et J. Baudry. Ciertamente no se había aventurado a depender de las informaciones locales; hombre ilustrado y lector asiduo, se había preparado para el viaje consultando obras sobre la historia y arqueología de México, Estados Unidos y Canadá, a más de otras sobre la civilización incaica. Alude a ellas en su texto, comentándolas al tiempo que registra sus propias observaciones, las cuales abarcan temas tan diversos como las condiciones geográficas y climáticas, la situación socioeconómica, cultural, política y religiosa de las poblaciones que visitó y, por supuesto, la flora y la fauna, que a menudo le merecieron descripciones entusiastas y muy bien logradas, ya que a sus conocimientos enciclopédicos aunaba una excelente pluma.

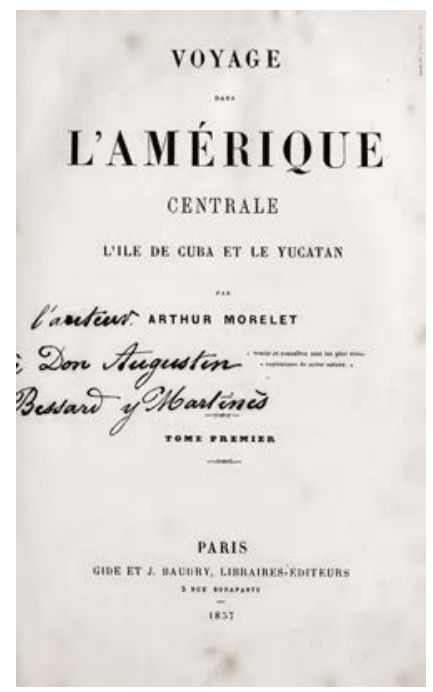

Figura 2. Frontispicio de su obra (Morelet,1857).

La variedad de temas y la extensión del escrito de Morelet incluye, a más de ilustraciones de su puño, ${ }^{2}$ brevísimas piezas musicales que escuchó a lo largo del recorrido, las que transcribió con los títulos de "aire de Yucatán", "aire indio", "aire de Tabasco, "aire de Petén", "aire de Honduras" (Figuras 3 y 4), ${ }^{3}$ agregando en algún párrafo: "La danza y la música, indicios de una vida libre y fácil, son distracciones desconocidas, y si casualmente tocan algunas melodías con sus groseros instrumentos, son cantos lastimeros, pues parecen llorar por los días de una felicidad remota y perdida".

\footnotetext{
${ }^{2}$ Agradezco a Roberto Romero, Alejandro Solís y Arturo Hernández, su apoyo para localizar y escanear las imágenes que acompañan este texto, y a los dictaminadores anónimos su cuidadosa lectura, que permitió fortalecer algunas de las ideas expuestas.

${ }^{3}$ Por el orden en el recorrido, es de suponer se refería al hoy Belice, entonces llamado Honduras Británica.
} 

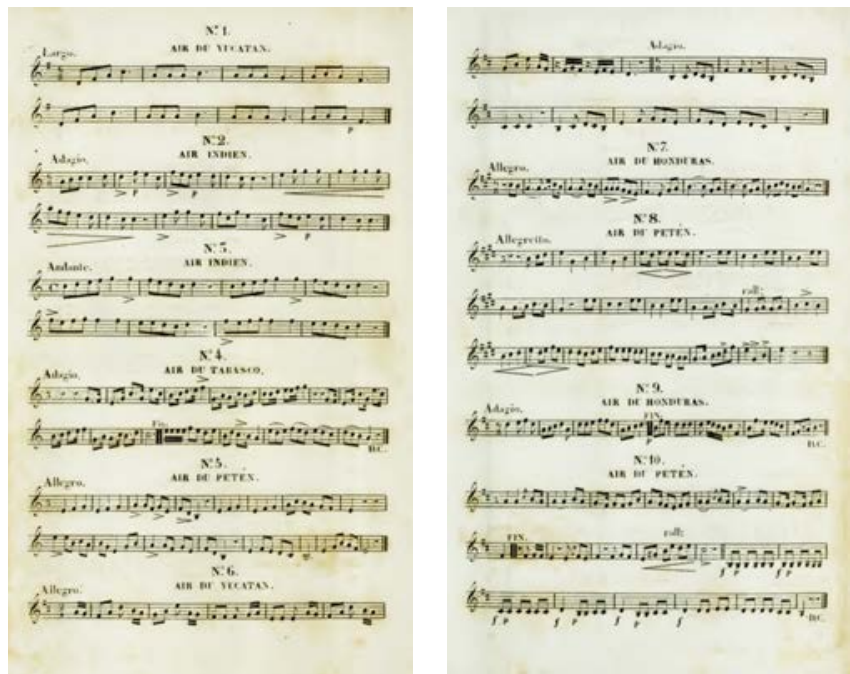

Figuras 3 y 4. "Aires" de Yucatán, Tabasco, Petén, Honduras e “indio" (sin especificar) (Morelet, 2018: 326-327).

Ya que es imposible dar cuenta detallada de todo ello, me referiré apenas a algunos de los capítulos que dedica a su travesía por el territorio mexicano que, como etnólogo, considero de valía para ilustrar la importancia de su obra y situarla en el contexto de su tiempo, en particular en lo que a sus apreciaciones sobre los pueblos de matriz mesoamericana toca. ${ }^{4}$ Lo hago a manera de invitación para su lectura, dado que recientemente vio la luz la primera edición completa del texto en castellano, coordinada por Carolina Depetris. ${ }^{5}$

Yucatán: paisaje monótono, comida abundante e indios inteligentes, impecables y de "genio alegre"

El viaje desde Cuba, concertado a mediados de febrero de $1847,{ }^{6}$ se anunciaba cómodo; a bordo de una goleta que, camino a Campeche, debía depositarlo en Sisal; goleta que le ponderaron como "la perla del golfo mexicano", de marcha

\footnotetext{
${ }^{4}$ Espero ello justifique ante el lector las numerosas citas, cuya procedencia exacta no indico a fin de aligerar la lectura, a menos que se trate de textos largos y, por ello, sangrados. Cabe advertir que, aunque con amplitud mucho menor, me he referido a este libro de Morelet en dos textos previos (Ruz, 1997 y 2015a), de donde tomo algún pasaje.

${ }^{5}$ En 1990 la Academia de Geografía e Historia de Guatemala publicó una traducción parcial del tomo dos, cuyo responsable no se menciona. La edición completa de la narración del viaje, sin las ilustraciones del original, vio la luz en 2015 (tomo I) y 2018 (tomo II).

${ }^{6}$ Las hostilidades entre México y los Estados Unidos, que desembocarían en el despojo de más de la mitad del territorio del primero, habían provocado una disminución de las embarcaciones disponibles.
} 
rápida y bajo el mando de un capitán amable y de trato liberal. Todo ello, apunta, le consoló del exorbitante pago que le exigieron por su traslado y el de su recién contratado ayudante, un joven marinero de apellido Morin que había pasado dos años confinado en Tabasco a causa de un naufragio, lo que le había proporcionado "cierto uso de la lengua española" que Morelet consideró le sería de utilidad.

No duró mucho el consuelo: durante la travesía no contó con "cama, ni colchón, ni una simple manta", y por todo alimento, "se nos puso a ración de galleta". ¿El trato? "Bastaba... considerar el traje y la desenvoltura del capitán, su sombrero deformado, sus pies desnudos en sus zapatos de cuero transformados en pantuflas, para hacerse una opinión sobre los modales de a bordo y la limpieza de la tripulación". Tras cuatro días de viaje bajo una lluvia torrencial, avistaron la costa yucateca, que según lo que había leído estuvo muy poblada antes de llegar los españoles, pero que para esa época, a lo largo de más de un centenar de leguas desde Cabo Catoche, no exhibía "más que una soledad inculta en la que han fijado su residencia algunos indios. Ningún puerto, ninguna bahía practicable ofrece un refugio al navegante que huye de los vientos del norte...”, exceptuando a Campeche, única ciudad "al borde de aquel arco inmenso que se extiende solitario hasta Veracruz".

El puerto de Sisal, que eligió desde Francia como punto de arribo para trasladarse a Mérida y desde allí a las zonas arqueológicas más reputadas por entonces, no era ni de lejos comparable al de Campeche. De hecho, una operación en principio tan simple como desembarcar se transformó en "casi un naufragio", cuando la barquilla en que debía hacer la travesía desde el barco hasta la costa, se vio arrastrada por la resaca. Tuvieron que jalarlos con cuerdas como se estilaba a menudo, según se enteró después.

Una vez en tierra comenzó a disfrutar de los frutos del país: el chocolate, los cigarrillos confeccionados con hoja de maíz, la hamaca y, por supuesto, la exuberante naturaleza continental, en buena medida novedosa para él, que se extendía sobre "el suelo pedregoso, desigual y cubierto, que reina generalmente en la parte septentrional de Yucatán". No menos novedosa le pareció la vida en Sisal, pequeño poblado donde se alzaban construcciones de troncos de maderas y huano, ${ }^{7}$ y de cuyos habitantes destacó tres detalles: la limpieza del atavío femenino, la bonhomía, "animación" y "buen humor" de la gente (que contrastó con lo generado por el régimen de esclavitud en Cuba), y la modorra que parecía imperar en la aldea, donde el movimiento - cuando no llegaba alguna embarcación de Campeche o las Antillas, o un carro tirado por mulas procedente de Méridaparecía limitarse a la veintena de indios que vigilaban y guardaban las costas:

[...] bajo aquella latitud, el reposo es una necesidad; las facultades mentales se adormecen y el tiempo parece plegar sus alas. La población india se pasa así la

\footnotetext{
${ }^{7}$ Apunta: “... hechas de estacas y cubiertas con la sombra de las palmeras", es de suponer en referencia a la especie Sabal mexicana, cuyas hojas se empleaban y emplean para los techos.
} 
vida, dormitando de padre en hijo, en una situación cómoda y precaria, los pocos españoles residentes puede decirse que se han indianizado: se trabaja sólo lo suficiente para subsistir y satisfacer el ocio; el resto de la existencia se la pasan liando cigarrillos, punteando el bandolín y meciéndose indolentemente en una hamaca (Morelet, 2015, t. I: 181). ${ }^{8}$

Al día siguiente tomó un carruaje que lo llevó a Mérida, en medio de matorrales y selva tropical baja. Camino de 11 leguas tristemente uniforme y monótono, a no ser por algunas plantas en floración y la multitud de aves ("vi papagayos, colibríes, grajos azules, cardenales con penacho, tángaras de plumaje brillante”). En Hunucmá, donde cambiaron el carruaje por caballos, pudo enterarse del linchamiento - estilo Fuenteovejuna - de un funcionario ocurrido días antes, aunque no consignó el motivo: "vi la plaza donde una multitud feroz usurpó el papel de verdugo; la piedra estaba todavía manchada de sangre; y aunque esa jornada hubo dejado en algunos espíritus una impresión siniestra, la opinión general absolvía a los asesinos, y las confusiones que agitaban la comarca les aseguraban la impunidad". Tuvo tiempo asimismo de probar las tortillas, que se le antojaron insípidas pero útiles para suplir la falta de cucharas. Ya dedicaría luego un detallado (y valioso) anexo a la manera de preparación no sólo de las tortillas, sino de otros productos elaborados con maíz como totopostes, tamales, pozol, atol e istatol, con comentarios elogiosos a las tortillas yucatecas, hechas con maíz de calidad y trabajo cuidadoso, lo que las hace "blancas e infinitamente superiores a todas las preparaciones del mismo género que se fabrican en Europa, sobre todo la polenta".

De Mérida le sorprendieron la extensión ("bien considerable”), la traza recta de las calles, conforme al llamado patrón de damero; las casas de poca altura y sobre todo, el hecho de que, yaciendo entre jardines y el monte circundante, fuese "preciso penetrar en ella para cerciorarse de su existencia". Ciudad, en su opinión, melancólica, que animaban apenas las aves que por las mañanas invadían los jardines saliendo de los montes, las "iguanas monstruosas" tendidas perezosamente al sol, los cantos de las aves domésticas...

Si el campo de Mérida lleva el sello de la monotonía, nada puede dar una idea de la tristeza reinante en la ciudad; las calles rectas y solitarias, prolongadas indefinidamente, la uniformidad de las casas ennegrecidas por el tiempo, las grandes plazas donde crece la hierba, el aspecto mezquino de las tiendas, la multitud de iglesias y el perpetuo sonido de las campanas dan a aquella capital decaída cierto carácter monástico, muy en armonía con las costumbres de los habitantes (Morelet, 2015: 185-186).

\footnotetext{
${ }^{8}$ Como señalé al inicio, sólo proporciono las páginas cuando se trata de citas sangradas. Aprovecho para mencionar que, con excepción de una cita (debidamente marcada), todas provienen del tomo I del libro.
} 
Más allá del sonido de las campanas, a los que se aunaban los provocados por el tránsito esporádico de alguna volanta "preciosamente cubierta con un lienzo gris que deja ver algunos dorados envejecidos", poco parecía turbar la monótona tranquilidad. $Y$ eso hasta cerca de las nueve de la noche, porque a partir de esa hora "todo se apaga, todo se adormece, sólo se escucha el ladrido de los perros cuidando de la choza india en la linde del bosque". A menos que una procesión religiosa, saliendo de alguna de las numerosas iglesias, pasease tal o cual imagen al resplandor de las antorchas o que, como ocurría tres o cuatro veces al año, se celebrase la fiesta de un santo popular, con regocijos públicos y corridas de toros. Por lo demás, apunta, los placeres de la sociedad eran escasos, y la vida se pasaba más bien en casa.

De guiarnos por su descripción, el ambiente poco animado obedecía al menos en parte al hecho de que la capital yucateca, "urbe de 24 o 25 mil almas", careciese de "comercio exterior" y atractivos para los extranjeros. Eso sí, la vida era mucho menos cara que en La Habana ("cuesta la mitad") y el mercado rebosaba de hortalizas ("especialmente la de los países tropicales, como cebollas, cohombros [pepinos], batatas, tomates, pimientos y berenjenas"), volatería y caza, mientras que de Sisal se aportaba pescado, por lo que no escaseaban los alimentos: "Se come bastante en aquel país a pesar de la intensidad del calor: una taza de chocolate y algunas pastas abren y cierran el día generalmente; en el intervalo, a las nueve y a las tres, se sirve la mesa con abundancia. Estas dos comidas son igualmente formales". "Las personas ricas" completaban su dieta con pan de trigo y vinos de España o Burdeos, y tampoco escaseaba el agua, de la que se surtía cada casa con pozos de apenas cinco metros de profundidad. Para "surtirse" de estudios superiores, en cambio, los jóvenes hidalgos se veían obligados a viajar a La Habana, "centro de la civilización en aquella comarca".

La arquitectura de la capital no le mereció mayores comentarios, exceptuando la catedral ("gran monumento") y lo que denomina "el palacio de Montejo" —la casa de la familia del adelantado Francisco de Montejo-, con sus esculturas, escudo de armas "y el nombre del conquistador de la comarca" en su fachada. Nada más.

Dedicó más tiempo a la gente del pueblo, esos hombres de "tez cobriza" que habían llamado ya su atención en Sisal, y que veía transitar, casi desnudos, arrastrando leña obtenida en los montes, mientras que las mujeres, vestidas de blanco, se afanaban por llevar al mercado "el producto de su industria". La población maya se diferenciaba por su número ("mayoritaria en todos los lugares públicos, especialmente en los mercados"), su atavío, su carácter y su apariencia física, que trajo de inmediato a su memoria las imágenes entrevistas en publicaciones sobre Chichén Itzá y Uxmal, ${ }^{9}$ y que contemplaría más tarde en Palenque. Describió sus

\footnotetext{
${ }^{9}$ Por la época de su viaje lo más probable es que haya podido consultar las obras de John L. Stephens o Benjamin Norman, a menos que haya visto los daguerrotipos de Chichén que se exhibieron
} 
frentes "deprimidas" y sus "narices alargadas", y se amparó en las semejanzas para tomar posición con respecto a la vieja polémica acerca de si habían sido los aborígenes locales los constructores de esos espléndidos asentamientos.

Como sabemos, el asunto, vinculado con el origen de los americanos, había interesado a los europeos desde épocas muy tempranas, y continuó siendo tema de discusión durante varios siglos. Apenas medio siglo antes del viaje de Morelet, por ejemplo, un grupo de ilustrados chiapanecos hizo una peculiar lectura de los dibujos de los estucos palencanos realizados por el capitán Antonio del Río, que, en su opinión, venían a "probar" la filiación grecorromana de los habitantes de esa urbe: una filiación que hacían evidente las representaciones de Plutón, Ceres, Proserpina, el Etna y el Hades, aunque curiosamente adobada con elementos hebreos y egipcios, entre otros. ${ }^{10}$

Un cuarto de centuria después, 1872, algún historiador seguía aludiendo a los orígenes hebreos de los americanos, ${ }^{11}$ y ya desde mediados de ese siglo xix un especialista tan reconocido como Brasseur de Bourbourg había postulado nexos entre las culturas maya y egipcia. Inspirados en no poca medida en las elucubraciones del francés, los esposos Augustus Le Plongeon y Alice Dixon llegaron incluso a invocar como origen de la civilización maya nada menos que a la Atlántida. Ella, autora de libros como Queen Moo's Talisman (1892) y A Dream of Atlantis (1909-1910), además de acotar que "las lenguas maya y griega tienen mucho en común", afirmaba que su esposo había podido leer las inscripciones en "caracteres mayas y egipcios" de una pirámide en Xochicalco, "copia exacta del monte sagrado de la Atlántida que describe Platón en el Timeo" (Dixon, 2001: 106, 114). Él, por su parte, en carta enviada al obispo yucateco Crescencio Carrillo y Ancona, se refería a las pruebas que había aportado en un artículo acerca "de la relación de la Creación del mundo (en Chichén) y los heroglyficos egipcios" visibles en monumentos que existían desde antes de la destrucción de “el país de 'Zimaan'”, parte de la Atlántida (apud Ruz, 2015b).

Bastante más pragmático, como era de esperar en un naturalista, Morelet sentenció, no sin ironía: "Un solo paseo a los mercados de Mérida me enseñó más acerca del origen de las ruinas que cubren la península, en comparación con las sabias disertaciones de que se había ilustrado mi mente". Opinó, asimismo, que los artistas nacionales habían exagerado "ciertos caracteres que constituían entonces el ideal de la belleza", pues las mayas de las cercanías de Mérida, a su parecer,

[...] rara vez son bonitas; son bajas de estatura; tienen los miembros gruesos, los pechos cónicos, la cara ancha, la boca algo grande, el labio superior muy arqueado,

en la expedición montada en París por Emanuel von Friedrichsthal en 1841. Agradezco a uno de los dos dictaminadores (anónimo), haber llamado mi atención sobre estos datos.

${ }^{10}$ Véanse al respecto Ballesteros, 1960, Garza, 1981 y Aramoni, 1991.

${ }^{11}$ Como el historiador tabasqueño Manuel Gil y Sáenz, quien atribuyó la "idolatría" de los mayas de Tabasco al hecho de haber perdido la tutela del "sabio y virtuoso patriarca" Zamná, "uno de los descendientes más inmediatos de Noé" (Gil y Sáenz, 1892: 8, 22). 
y tendencia a engordar. La nariz ligeramente deprimida, los ojos entreabiertos y ligeramente levantados en su ángulo externo, el cabello negro y lisos sin muchas canas, la tez cobriza y algunas veces amarillenta, presenta un conjunto de caracteres similares a las de las tribus de origen mongol (Morelet, 2015: 187).

Las mujeres mestizas, a su parecer, "tienen unos rasgos mucho más agradables; su fisonomía carece quizá de expresión y de viveza, pero se desprende de ellas esa dejadez ${ }^{12}$ meridional atribuida más a la voluptuosidad que a la debilidad" (Figuras 5 y 6).
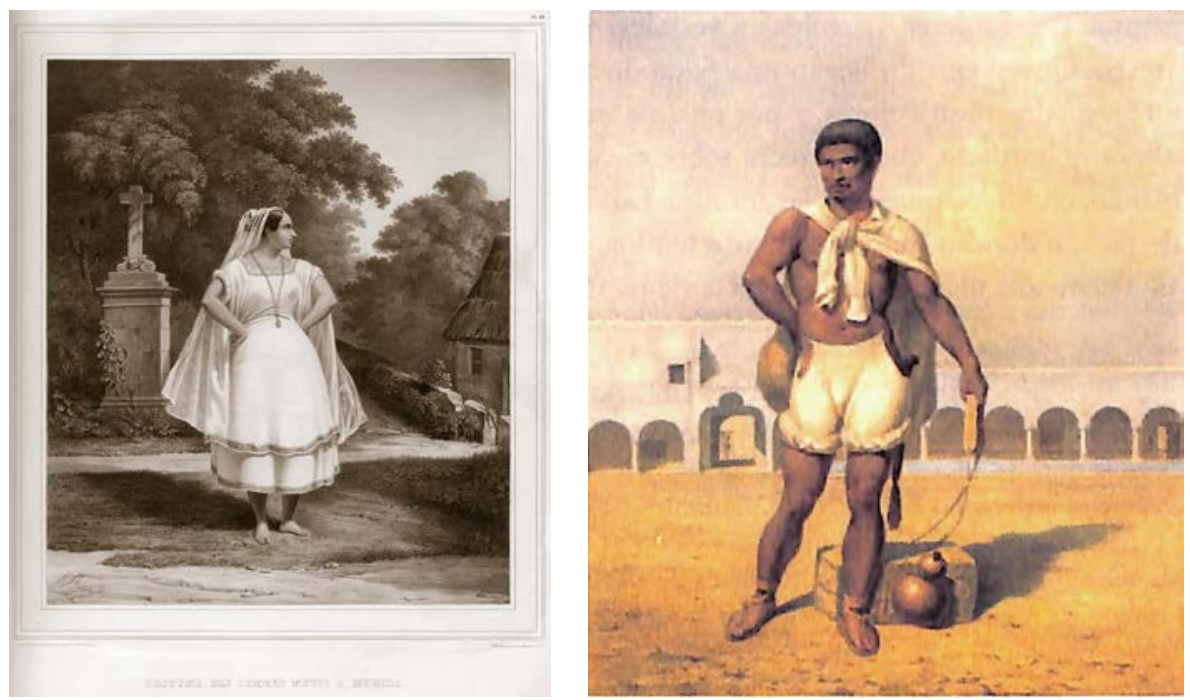

Figuras 5 y 6 . Mestiza de Mérida e "indio contrabandista" (Waldeck [c. 1838], 1996: 206, 209).

Si, desde su óptica —que no necesariamente compartieron otros europeos— ${ }^{13}$ rara vez podían considerarse bonitas, las mujeres mayas eran en cambio, apuntó, extremadamente limpias, tanto en su persona, ${ }^{14}$ como en su atuendo, el cual describió junto con el de los hombres:

La vestimenta que llevan aquellos indios es idéntica en todo Yucatán; no hay nada más sencillo ni más apropiado al clima: compuesta del mismo número de prendas y de la misma tela para ambos sexos, en los hombres es un pantalón ancho reman-

${ }^{12}$ La edición guatemalteca consignó "languidez que tiene más de voluptuosidad que de debilidad" (1990: 27), traducción que se antoja más apropiada.

${ }^{13}$ Tres siglos antes fray Diego de Landa calificó a las mayas de Yucatán como "en general de mejor disposición que las españolas, y más grandes y bien hechas" (Landa, 2003: 114), buena muestra de que las apreciaciones estéticas varían con el tiempo y los propios individuos.

${ }^{14}$ Destacó la costumbre, compartida con los hombres, "en un país donde el agua no es abundante, de lavarse escrupulosamente todos los días". 
gado todo lo que se puede y una camisa corta y suelta fuera del pantalón, al revés de lo usado en el mundo civilizado; en las mujeres es una falda estrecha (fustán) ceñida alrededor de las caderas, y una camisa más corta, ésta deja ver los bordados adornando la parte inferior de la falda. Ningún cinturón dibuja su talle, disimulado debajo de la ropa. Además se cubren con una especie de mantilla cuando van a la ciudad, y los hombres con una manta rayada, pero sólo cuando el termómetro baja a 17 o 18 grados. En el campo la vestimenta se simplifica con la supresión de las prendas superiores; los hombres se quedan con su pantalón y las mujeres con su falda (Morelet, 2015: 186-187).

Sus consideraciones acerca del atavío y la pulcritud son semejantes a las de muchos otros europeos, comenzando con los frailes españoles ${ }^{15}$ e incluyendo a la emperatriz Carlota, que visitaría la Península en $1865 .{ }^{16}$ Con ella compartiría también la impresión de que los mayas eran gente muy trabajadora y dotada de una inteligencia peculiar, pues si él consignó: "Desde el punto de vista intelectual, la raza indígena me ha parecido más adelantada en Yucatán a las radicadas en otros puntos del continente americano en donde he estado en contacto con ellas; su superioridad procede sin duda del origen; sin embargo, la configuración del país también desempeña un papel”, Carlota, de regreso de su viaje, escribiría desde Cuernavaca a su suegra: "Yucatán es la región de México donde el corazón y la inteligencia se encuentran más desarrollados". ${ }^{17}$

La impresión sobre el "buen humor" maya que llamó su atención apenas desembarcar en Sisal, la corroboraron su estancia en Mérida y su paso por el resto del estado: "No he notado en los indios de Yucatán un carácter tétrico o taciturno, como nos pintan a los de la América del Norte; al contrario, me maravillaba su humor alegre...", mientras que las labores que desempeñaban en la ciudad, casi siempre a favor de los criollos y mestizos, le merecieron el siguiente comentario:

Los hombres son campesinos y leñadores; proveen los mercados, ejercen ciertas industrias en las ciudades, tejen por sí mismos y saben teñir las telas de algodón usadas para su vestimenta; las mujeres trabajan en casa de las familias españolas, donde hay siempre media docena de criadas indígenas: una cuida a los niños, otra se encarga de la casa, ésta prepara las tortillas, aquella prepara la comida; también se necesita a una para preparar las hojas de maíz con las cuales se hacen los cigarros, etcétera. Aquel lujo de sirvientas se debe a los módicos salarios ofrecidos a la servidumbre, los cuales se reducen a ofrecer comida y ropa (Morelet, 2015: 188). ${ }^{18}$

${ }^{15}$ Landa apuntó que las mujeres eran particularmente limpias "por cuanto se lavan como los armiños". Agregó que se untaban con ungüentos colorados y, las más pudientes, cubrían pechos, brazos y espalda con una goma como liquidámbar, iztah te, “y quedaban galanas y olorosas, según les parecía" (Landa, 2003: 115 ss.).

16 Véase al respecto, Ruz, 2011.

${ }^{17}$ Carta a la archiduquesa Sofía. Cuernavaca, 1o de febrero, 1866 (apud Weckmann, 1989: 119).

${ }^{18} \mathrm{Y}$ a veces ni siquiera módicos, si nos atenemos a lo que escribió Carlota a Maximiliano durante su visita: "A los sirvientes y sirvientas se les adeuda porque sus jefes no les pagan; sólo les regalan ropa. Y los castigan cuando la echan a perder" (apud Ruz, 2011: 190). 
Uno de los objetivos de su viaje era visitar las ruinas de Uxmal, cuyos "restos notables" había podido apreciar en las descripciones de Waldeck y Stephens y en los grabados de Catherwood, pero no pudo cumplirlo ya que "se acababa de producir una revolución; era la cuarta en el espacio de un año", así que decidió continuar viaje a Campeche, no sin dedicar unos párrafos a las luchas intestinas y a los enfrentamientos con las fuerzas del centro del país, comandadas por Santa Anna; a la añeja rivalidad entre Mérida y Campeche, expresada en continuas luchas, y registró también la explosión de lo que denomina "el odio hereditario de los indios contra los españoles", que para cuando apareció su libro (1857) había dado pie a un levantamiento de los mayas, más tarde conocida como Guerra de Castas, que vino a sumarse a la contienda entre emeritenses y campechanos.

Convencido de que lo mejor era alejarse antes de que el incendio le quemase, y, pagando cuatro veces el costo normal, halló quien lo condujera hasta Campeche, siguiendo el Camino Real: Umán, que encontraron desierto, y Chocholá, "ocupado por la retaguardia de los insurgentes"; 300 efectivos cuya descripción parece justificar bien el calificativo de "horda" que le dedica:

Aquellos guerreros andaban a la desbandada, su capricho era su única regla; todos iban armados con fusiles; su vestimenta consistía en un pantalón blanco remangado hasta medio muslo y una camisa suelta fuera del pantalón, un atavío poco militar. Algunos hasta habían encontrado la manera de simplificar aún más el uniforme; por su tez cobriza, sus músculos salientes y su corpulencia más robusta eran reconocibles aquellos cuya sangre se había mezclado con la raza africana. Los oficiales, con casaca y sombrero de paja, parecían más bien cultivadores; la mayor parte iba mal calzada y caminaba algo apesadumbrada, bajo un sol ardiente y 40 grados de calor (Morelet, 2015: 194).

El estado de desorden y descontento que percibió a lo largo del trayecto, ${ }^{19}$ no le impidió reparar en ciertas características del entorno:

Los pueblos, y las pequeñas aldeas de Yucatán, me han parecido construidos con un plan regular y uniforme; me llamó la atención su buen orden, su limpieza, los edificios públicos que los adornan y el lujo de sus jardines, fruto casi exclusivo de la naturaleza, es preciso decirlo. Las calles son anchas, orientadas y trazadas a cordel; en el centro se halla la plaza, dominada por una iglesia con cierto mérito arquitectónico. En el frente opuesto se erigen los edificios municipales, con sus arcadas para proteger a los viandantes del sol; al lado están las viviendas principales, entre las cuales hay uno o dos almacenes provistos de todo lo necesario para vivir. Hay pocas aldeas en Francia, no dudo en afirmarlo, que puedan ofrecer los mismos recursos, y cuyo aspecto sea tan agradable (Morelet, 2015: 195-196).

19 “Los jefes se notaban disgustados, los soldados indiferentes, el resto de la población, intranquila. Los mercaderes se apresuraban por hacer desaparecer sus productos; durante la última campaña les habían decomisado todo las dos partes beligerantes, y su entusiasmo patriótico se había enfriado como consecuencia de ello; si acaso intentaban disimular un poco su escasa simpatía por la causa nacional" (Morelet, 2015: 195). 
El viaje continuó por Maxcanú y Halachó, donde se topó con "la vanguardia enemiga"; las tropas campechanas, compuestas por cerca de mil soldados "apoyados por una artillería respetable" (contra las apenas dos piezas que portaban los de Chocholá), ante las que terminaría capitulando Mérida "en medio de la deserción general. La causa insurreccional no tenía efectivamente raíz alguna entre la población: todos parecían estar cansados con aquellas rivalidades entre familias, y con aquellas luchas sin gloria ni provecho, cuya consecuencia era ensangrentar el país según los caprichos de un puñado de ambiciosos". No ocurrió lo mismo con el alzamiento indígena, pues buena parte del pueblo maya, al que las facciones habían armado y aguerrido, "emprendió rápidamente y por su propia cuenta una cruzada nacional que abrasó toda la península, y cuyo fuego sólo ahora está apagándose" (2015: 198). ${ }^{20}$

\section{Campeche: de la belleza del paisaje y la explotación de los hombres}

La entrada al puerto no dejó de ser original (Figuras 7 y 8). El carricoche, tirado por tres caballos secos, que imaginó se hallaban entre los más miserables de la cuadra y quizá de la ciudad, y manejado a saltos por un conductor tan borracho que, ante el azoro de los pasajeros, terminó por caer redondo en el interior del vehículo, penetró a Campeche el 5 de marzo de 1847, después de 60 horas de agitado y tenso viaje desde Mérida.
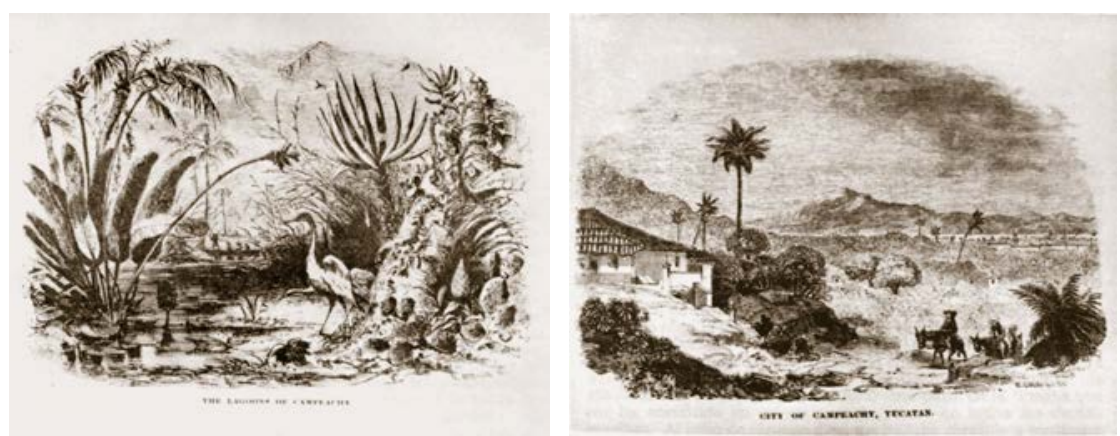

Figuras 7 y 8 . Lagunas y entrada a Campeche $\mathrm{C}^{21}$

(Morelet, 1990: 13, 47).

De Campeche le gustaron la ubicación, el aseo y el orden. La primera se le antojó "una de las más privilegiadas" que había visto en América, mientras que

${ }^{20}$ Cabe señalar que esta referencia a la llamada Guerra de Castas corresponde a la época de escritura del texto, no a la del viaje del autor, pues, como se apuntó antes, cuando Morelet pasó por la Península el levantamiento no había iniciado. Y no se "apagaría" tan pronto como él pensaba; tardaría medio siglo más.

${ }^{21}$ Conviene advertir que no todas las ilustraciones están tituladas en el texto original. 
los segundos, que reinaban "por todas partes", le parecieron contrastar "ventajosamente con la negligencia fastuosa de La Habana”. En cambio, exceptuando las murallas almenadas, no encontró en el puerto monumento alguno digno de destacar. Su plaza mayor, "bastante fea" y la parroquia, que erróneamente consignó como catedral, "mezquina”. 22

El clima no salió mejor librado: "ardiente e insalubre”, "humedad salina”, propicia a fiebres intermitentes y al temible vómito. Y por si fuera poco, tres plagas: los alacranes que abundaban en las oquedades del palo de tinte amontonado en los muelles, desde donde invadían la ciudad; los insoportables mosquitos ("miserable pigmeo" capaz sin embargo de hacer inhabitable un territorio, reflexionó) y un ejército de garrapatas, "uno de los animalejos que la Providencia ha sacado de la nada con un propósito indiscernibles para nuestra imaginación”. Famélicas de ayuno, cualquiera de estas últimas se apresuraba a trepar por las piernas de quien se pusiese a su alcance. "Bien pronto elige su objetivo; su cabeza penetra en las carnes, sus patas se adhieren y ya no es fácil arrancarla. Mientras chupa activamente la sangre, se la ve hincharse; de un estado de flaqueza extremada, pasa el insecto a una obesidad exagerada; las paredes de su abdomen se dilatan, y su volumen aumenta de día en día”, para terminar, obesa y saturada, desprendiéndose por sí misma y rodando al suelo "como un borracho".

La larga y entretenida descripción sobre las garrapatas, sus hábitos y las formas de liberarse de ellas (con alcohol, tabaco o arrancándolas directamente, con lo que se arriesga dejar partes de ellas adheridas al cuerpo, pues "prefieren dejarse hacer pedazos antes que soltar su presa”) es particularmente lograda, pero carece de la clara simpatía que le produjo el asalto de la naturaleza campechana transfigurada en cazón, que se menciona varias veces en el texto:

Pronto los vi de todos los tamaños, formas, colores: cazones de martillo, cazones de hierro, cazones de hacha, cazones de hocico puntiagudo; blancos, negros, grises. En total, cinco especies de tiburones. Los había frescos y salados, asados y cocidos, para todos los gustos en suma. Sabía que aquellos escualos pululaban en el banco de Campeche, pero ignoraba el culto gastronómico del cual eran objeto (Morelet, 2015: 199).

Vinieron luego los vegetales ofrecidos con profusión en un mercado que, en su opinión, no dejaba nada que desear desde el punto de vista del aseo y el buen orden, y mucho menos en lo que tocaba a la limpieza de las comerciantes mayas, que, de nuevo, halló impecables.

[...] como en Mérida, admiré, al visitarle, la pulcritud de las indias sentadas en largas filas, unas doscientas o trescientas, junto a los objetos de su comercio. Se

\footnotetext{
${ }^{22}$ La diócesis de Campeche fue creada por bula de León XIII casi medio siglo después, el 18 de mayo de 1895. Su primer prelado, Francisco Plancarte y Navarrete, tomó posesión de ella hasta el 26 de noviembre del siguiente año.
} 
trata de frutas, flores, pimientos [chiles] variados, cebollas, frijoles negros, limones silvestres, patatas no muy ricas en aquel lugar, batatas, ñames, una gran variedad de otras cucurbitáceas y solanáceas y, finalmente, huevos, algunas gallinas y el inevitable cazón. El miércoles y el viernes se pueden también conseguir tortugas; no me atrevo a decir en qué estado se ofrecen estos animales a los parroquianos, porque el trato que se les da sin duda indignaría al lector (Morelet, 2015: 199).

Ya que entre los frutos expuestos a la venta, se encontraban dos nuevos para él: el caimito y la anona (los cuales, curiosamente, no vio en el mercado de Mérida), se entretuvo en describirlos. Apuntó que la forma y el color de la segunda le habían valido el sobrenombre de corazón de buey (cœur de bœuf) que le daban los franceses en las colonias, y comparó, cosa extraña, el sabor del primero con el de la fresa, mientras que la anona se le antojó de "un sabor muy frío y muy particular; ésta produce en el paladar la impresión de una crema perfumada”. Llamó también su atención la manera en que los vecinos suplían la escasez de moneda circulante: partiendo el llamado medio, "en dos, en tres y aun en cuatro fragmentos. Cada mitad vale un cuartillo, y cada cuartillo dos chicas", o recurriendo nada menos que a un valor de cambio prehispánico: el cacao, que se hacía equivaler de 80 a 160 granos por un medio, según que tanto abundara en la plaza; "cinco granos de cacao son la última expresión del sistema monetario".

A diferencia de la ciudad, la visión de los "arrabales" desde "el cerro de San Francisco", al salir el sol, lo entusiasmó:

No hay nada tan lindo como la perspectiva de los arrabales, donde una población de diez mil almas vive esparcida en magníficos parajes sombreados, desde la playa sembrada de cocoteros hasta el anfiteatro de colinas que cierra el horizonte [...] Desde aquellas alturas, la mirada abarca un paisaje de verdor y de casitas blancas del aspecto más pintoresco. A lo lejos se ven los edificios salientes y los campanarios de la ciudad, destacados con luminosidad sobre la extensión azulada del Golfo (Morelet, 2015: 200-201).

Dedicó también algunos párrafos a describir el paseo de naranjos que ornaba la puerta de Santa Ana y el cultivo de los jardines (que asegura fomentó su compatriota, el cónsul M. Laisné de la Ville-l'Évêque), para retornar a las plantas que descubrió en la campiña y las playas circundante, destacando a la pitahaya, cuyos frutos calificó de "los más hermosos y de mejor gusto producidos por los vegetales de aquella tribu” de cactáceas.

De allí pasó a referirse a "una colección bastante preciosa de antiguiedades americanas" que habían formado dos eclesiásticos originarios de Canarias, los hermanos Camacho, con "figuritas y vasijas de barro con algunas marcas de pintura y de barniz, instrumentos de música, varios objetos de adorno, hachas, puntas de lanza de pedernal o de obsidiana, etc.", ${ }^{23}$ que le confirmaron en la opinión

23 Sobre esta colección, y su importancia como antecedente de los museos peninsulares, véase Sellen, 2010. 
"en cuanto al retraso del arte plástico y el de dibujo en Yucatán, en una época en que la arquitectura había hecho ya notables progresos entre los habitantes”. ${ }^{24}$

Ya que lo que realmente le interesaba era la naturaleza, abandonó la ciudad pocos días después y trepó a un buquecito que partía hacia Isla del Carmen. Estaba en el puente despidiendo de sus nuevos amigos, cuando iniciaron el viaje encallando en la arena. Pasó la noche entre dos sacos de arroz y bajo un calor sofocante pese al norte que se anunciaba. "Bañado en sudor y respirando a duras penas, me sentía desfallecer en aquella atmósfera mefítica, mientras mil insectos desconocidos zumbaban o se agitaban a mi lado [...], las olas rompían con violencia y las tablas crujían como si su armazón estuviese a punto de quebrarse". Apenas había conciliado el sueño cuando, al rayar el día, lo despertó la voz del patrón del buque: “Señor, ¿desea ir a tierra?". Se puso de pie de un salto, contento de haber salido bien librado del viaje. Frente a él se erguían las murallas almenadas y los campanarios de Campeche. iEl norte había obligado al barco a regresar a puerto!

Tres días después pudieron volver a bordo. Desde la nave contempló Champotón y cerca de la "rada de Ceiba” [Seibaplaya] observó un banco de ostras, de una especie "más conocida por los glotones de Campeche que por los naturalistas", cuyo excelente sabor comprobó más tarde. Vio luego las montañas de palo de tinte (Hematoxylum campechanium) apilado en El Carmen en espera de ser exportado a Europa, y se aterró ante la masacre forestal, pues el corte, apuntó, "desprotegido por cualquier reglamento, [la especie] decrece con rapidez y se puede anticipar el momento en el cual la codicia de los propietarios, deseosos únicamente de una ganancia actual e inmediata, habrá agotado su fuente de alimento".

La indolencia que creyó percibir en los carmelitas aferrados a la extracción forestal, de la cual obtenían todos sus bienes gracias al tráfico marítimo, le mereció comentarios poco elogiosos:

La naturaleza ha disfrazado la pobreza de la isla de El Carmen bajo un manto de verdor engañoso y agradable a la vista. Al ver aquella vegetación, cuya expansión es a veces vigorosa, los habitantes han pecado por falta de habilidad o de perseverancia. En efecto, la costumbre de cosechar sin esfuerzo se halla tan arraigada en el Nuevo Mundo español, al grado de abandonar cualquier tierra si no corresponde súbitamente a las exigencias del cultivador. Las landas de El Carmen, cubiertas de un soto cerrado o de gramíneas, podrían sin duda producir algo más útil al hombre; la aridez del suelo es superficial; a poca profundidad se encuentra en todas partes el agua o a lo menos la humedad salina, mantenida por la atracción capilar de la arena (Morelet, 2015: 250).

Esa misma riqueza del medio le parece subyacer en "la apatía de los más necesitados", contra cuya indolencia poco podían patrones como un tal M. Johnson,

\footnotetext{
${ }^{24}$ Aprovechó lo que consideró representaban algunas piezas para hablar del sistema judicial y penal de los antiguos mayas.
} 
"quien hacía loables esfuerzos por convencer a aquella población inerte de que con un poco de industria y de esfuerzo obtendría de aquellas tierras abandonadas recursos suficientes como para satisfacer sus necesidades". La gente se conformaba con el salario de un peso, y si aceptaba trabajar durante una semana, era tan sólo "para adquirir el derecho de no hacer nada en un mes". Problema propio de la América española, a donde había que viajar

[...] para encontrar a aquellas personas que su pobreza hace tan ricas, colocándolas por encima de todas las necesidades; ningún incentivo las estimula en cuanto tienen lo estrictamente necesario; para ellas el bienestar consiste en el reposo; su ambición se limita al alimento cotidiano [y] en cuanto a su familia, encomiendan a la Providencia el cuidado de velar por su porvenir. Así se prolonga en ellos la indiferencia por el mañana, sin mejora, sin progreso, desde la cuna hasta el sepulcro (Morelet, 2015: 250-251).

Más allá de consideraciones de ese tenor, y algunas opiniones favorables sobre la piedad que advirtió en las casas y en las iglesias (con esa "poesía indiscutible, capaz de llegar directamente al corazón” propia de las ceremonias del culto católico), la rutinaria vida humana bajo el sopor tropical parece haberle fatigado pronto. Eso sí, su "curiosidad excitada, jamás” se cansaba de contemplar el paisaje de la isla y la Laguna de Términos. Ante la exuberancia de la vida vegetal y animal, su "imaginación europea” se mecía "en las regiones de lo desconocido":

La naturaleza no produce allí nada insignificante: el destino de los fluidos vegetales no se limita a las funciones de la especie; la savia ardiente que vivifica las plantas y penetra sus tejidos está casi siempre dotada de virtudes específicas, con las cuales establecen nuevos lazos entre aquellos cuerpos organizados y el resto de la creación. iCuántos principios desconocidos entre tantas ruinas, gomas, esencias aromáticas u oleosas, jugos lactescentes casi animalizados, esperan para fecundar nuestras artes o nuestra industria, para enriquecer el dominio de la medicina, a que una circunstancia casual revele un día sus propiedades! [...] .

No hay nada más complejo que la hidrografía de aquel pequeño rincón del mundo, donde las aguas, indecisas, corren lentamente de laguna en laguna y parecen seguir rumbos distintos. En tiempo de sequías cada sistema tiene su lecho distinto [...] cuando llegan las lluvias, las lagunas se llenan, se hinchan y se extienden en sus receptáculos naturales [...]. Una vez más resultan imprescindibles todos los recursos de la experiencia para no perder el hilo de aquel laberinto acuático [...].

En los límites de la laguna comienza el dominio de la naturaleza; los animales salvajes rugen en la selva; los reptiles se enlazan al tronco de los árboles; los mosquitos toman posesión de la atmósfera; el hombre no es ya el amo de la creación, sino un viajero extraviado [...] (Morelet, 2015: 252-256) (Figuras 9 y 10). 

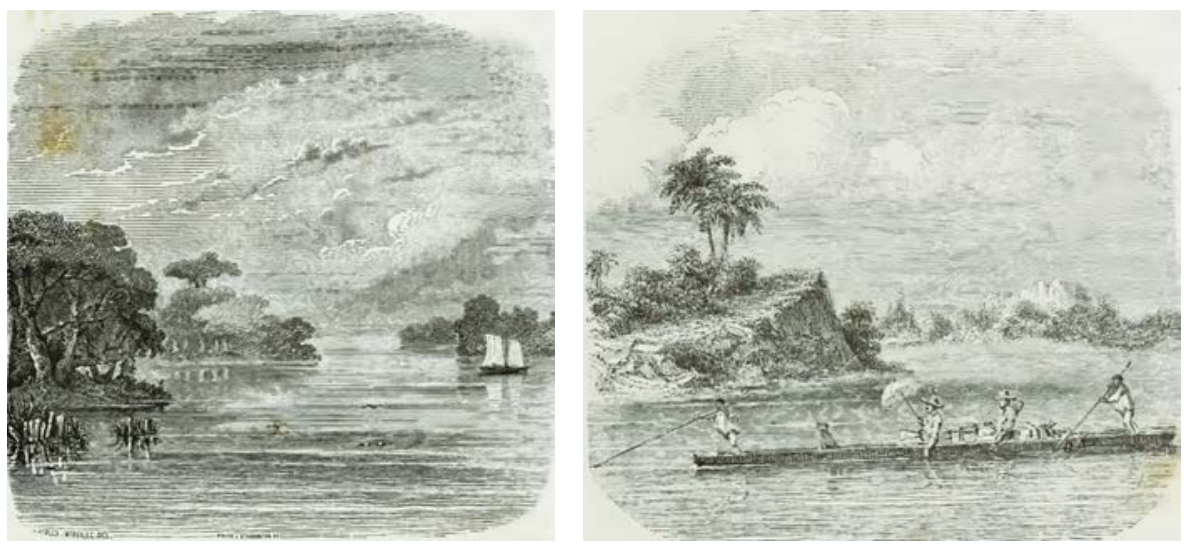

Figuras 9 y 10 . Vistas de la región

(Morelet, 2015: 213, 299).

En su trayecto rumbo al Usumacinta, que inició el 24 de marzo, al franquear el paso de Boca Chica lo asaltó la belleza arbórea de las márgenes, tal y como había ocurrido a Tomás de la Torre, dominico compañero de Bartolomé de las Casas, que describió la región por primera vez, en 1545. Apuntó por entonces el fraile que "el camino [a Xicalanco] era el más fresco que jamás hasta entonces habíamos visto: partes era todo cerrado de árboles de diversas maneras, que no veíamos el cielo, otras parte iba por unas dehesas tan anchas como un tiro de ballesta, y a las veces más y menos, y por las orillas arboladas, fresquísimas" (Torre, 1975: 341), mientras que los "remates" de los ríos que desembocan en Términos, "llenos de fresquísimas arboledas", se le antojan "un traslado del cielo" y las riberas del que llamaron San Pedro y San Pablo estaban "cubiertas de muchos y hermosos árboles, que es para alabar a Dios. No parece sino que a posta lo han entoldado para [la próxima fiesta de] el Corpus Christi” (apud Ximénez, 1975: 341, 345).

Al leer las descripciones de Morelet puede apreciarse que, justo tres siglos después de que los dominicos arribaran a la zona y pese a la brutal tala de manglares, tintales y maderas preciosas que experimentaba por entonces, su riqueza forestal seguía siendo capaz de impresionar incluso a un naturalista tan conocedor y experimentado, al grado de hacerle escribir: "Nada puede dar una idea de la selva que costea la ribera, y extrae de la frescura de las aguas una eterna juventud", o de "los millares de aves" que las poblaban.

Vino luego el encuentro con el Palizada, "grandes sauces de ramas lloronas, bambúes gigantescos, hermosas ciperáceas semejantes al papiro, palmeras acuáticas de tronco delgado y anillado, y cecropios de anchas hojas [...]"; después, "masas de vegetación matizadas de racimos violáceos, troncos blanquecinos y prodigiosos, lianas delgadas y tensas como las cuerdas de un buque”. Y de nuevo las aves: el plumaje brillante del ibis, la voz sonora del aramo o carrao, el pro- 
fundo azul de la gallina de Moctezuma, el vuelo rasante del martín pescador de collar, los gritos agudos de los halcones...

Transcurridas 54 horas de viaje aparecieron las sabanas que bordeaban la villa de Palizada; allí donde

la vista puede errar libremente por la extensión ondulada de las sabanas. Los rayos del sol poniente inundaban aquellos prados donde reinaba una inmensa paz; los sauces inclinados sobre el río, los charcos de agua luminosa, los rebaños, las selvas lejanas, componían un conjunto que me cautivó de manera singular [...] Al desembarcar supo de la hospitalidad de los lugareños; esa hospitalidad 'fácil de ejercer en el trópico', [pues] con dos clavos y unos metros de tela [para la hamaca], el dueño de una casa está siempre en disposición de recibir y de contentar a sus huéspedes (Morelet, 2015: 262).

Se enteró más tarde de que, pocos años antes el poblado "era sólo una miserable aldea, exclusivamente habitada por indios", pero la explotación del tinte había provocado cambios radicales al convocar primeros a "jóvenes de color, sin familia y sin fortuna, de una raza desheredada" y más tarde a comerciantes, sastres, barberos y varios otros "atraídos por la esperanza de participar de los beneficios de aquella pequeña sociedad naciente". ${ }^{25}$ Pese a que la villa oscilaba entre períodos de bonanza y otros de miseria, muchos de ellos habían satisfecho tales esperanzas gracias a la especulación: "comprar al precio más bajo en la localidad, para vender lo más caro posible en la Laguna”, o a la explotación de los trabajadores.

[...] a pesar del elevado costo de los salarios, el propietario, para sacarle partido a sus tierras, tiene como único recurso la servidumbre personal impuesta por la ley al deudor. Ya expliqué anteriormente cómo los indígenas caen en la trampa; añado aquí que antes de recibir la menor retribución en dinero metálico deben reembolsar a su patrón el costo de mantenimiento, sobre el cual este saca un beneficio del 60 u 80 por ciento. Así pues, el obrero desdichado permanece endeudado y, por consiguiente, esclavo toda su vida; no se podrá objetar que esta servidumbre es voluntaria, porque la voluntad pierde su carácter esencial cuando se condiciona mediante la seducción y la ignorancia (Morelet, 2015: 266).

Tras registrar la carestía que caracterizaba a la villa y los precios exorbitantes que exigían los trabajadores, y externar su sempiterno enfado ante una población que, poseyendo un territorio de fertilidad incomparable, rehusaba sacar partido de él, Morelet concluyó que "el cuadro de la civilización naciente dista mucho de ofrecer, en la Palizada, un interés tan grande como el de la naturaleza salvaje" (Figura 11). En consecuencia, el naturalista abandonó a los hombres y retornó a regodearse con la descripción de las aves, al "número infinito" de zancudas y palmípedos que "nadan, se sumergen y atraviesan continuamente los aires"; al pico huesudo del tántalo, al plumaje rosado de la espátula, la blancura nívea de la garzota, las alas color de fuego del flamenco, el paseo solitario de la grulla,

${ }^{25}$ Varias de las apreciaciones de Morelet sobre Palizada se corroboran y amplían en un acucioso estudio de Torras Conangla, 2012. 
las aves de rapiña que se arrojan al pantano pensando encontrar alimento, para terminar en las fauces del caimán oculto...

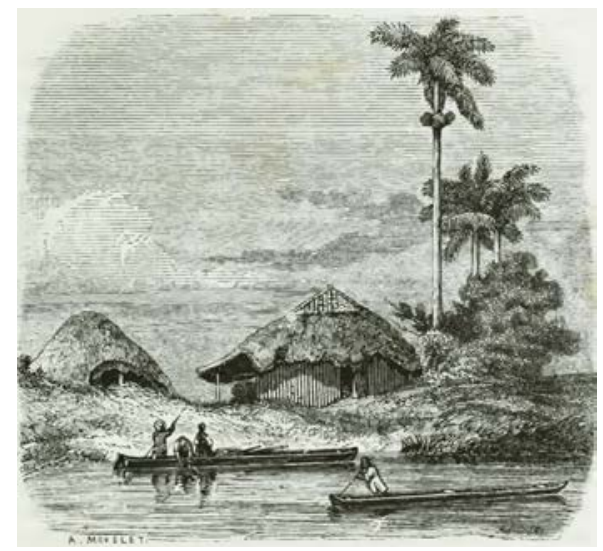

Figura 11. Sin título (Morelet, 2015: 245).

\section{Asomo y asombro por Chiapas}

Pese a su mayor interés en la naturaleza que en las creaciones culturales humanas, no pudo sustraerse al placer de visitar el asentamiento prehispánico de Palenque que tanto ponderaban los viajeros que le precedieron, y a quienes con tanta atención había leído, como lo hace expreso en sus notas, al historiar el descubrimiento del sitio en 1750 por Antonio Calderón, "intendente de Chiapas"; las dos exploraciones efectuadas por orden de la Monarquía en 1784 y 1785, el reconocimiento formal, 18 años después, ordenado por Carlos IV; las contribuciones de Dupaix, Waldeck y Stephens ("dos viajeros especuladores"), ilustradas por Castañeda y Catherwood...

Del Palizada al Usumacinta, de éste al Río Chico, y por el arroyo Chiquito y la laguna de Catazajá (con sus márgenes pobladas de tapires, monos, caimanes y numerosas aves), Morelet llegó a lo que denomina aldea de Las Playas (hoy Playas de Catazajá) buscando Santo Domingo de Palenque. En Playas, al acudir a la casa de Cabildo, pudo constatar la persistencia de la legislación colonial, que ordenaba proporcionar alojamiento a los viajeros.

Una veintena de lazzaroni indígenas obstruía la entrada, tendidos en el suelo, donde gozaban la existencia en un estado muy próximo al de la naturaleza. Fue necesario pasar por encima de ellos para tomar posesión de nuestro domicilio. Aquellos salvajes, originarios de las montañas de Tumbalá, descienden de vez en cuando a la llanura con el fin de intercambiar sus productos por otros artículos. Sus facciones eran muy poco atractivas: tenían la cabeza puntiaguda hacia el occipucio, la frente estrecha, los miembros gruesos y la tez bastante clara; embriagados desde la mañana hasta la noche, hablaban un idioma entendido por pocas personas (Morelet, 2015: 281-282). 
Exceptuando notas como la anterior, ${ }^{26}$ Morelet dedicó pocos párrafos a los vecinos chiapanecos. Su atención se centró en la naturaleza, cuya exuberancia y belleza en el entorno palencano lo dejaron "tan sorprendido como maravillado", ya que los "eruditos" autores de las obras que había leído, deslumbrados por el espectacular sitio arqueológico, "han tratado como un accesorio sin valor el cuadro que rodeaba al objeto de sus especulaciones” (Figura 12).

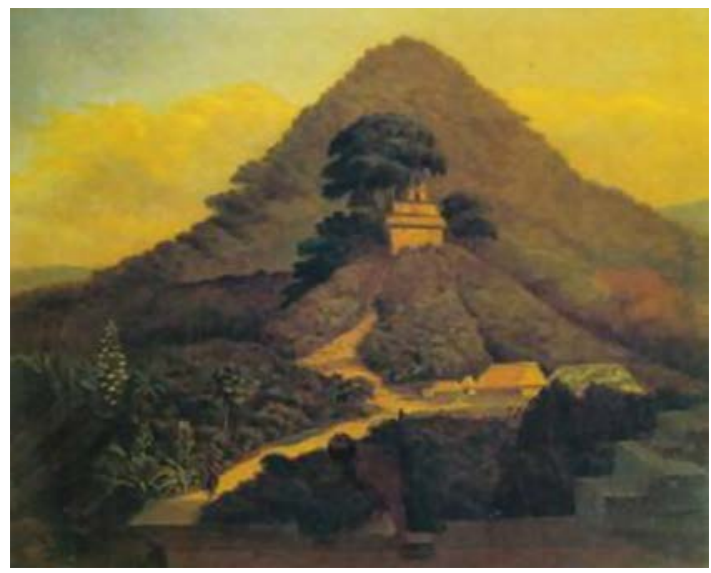

Figura 12. Palenque, Templo de la Cruz (Waldeck, apud Baudez, 1993: 113).

Se refiere, así, al esplendor de las colinas arboladas, la claridad de arroyos como el Chimichibol, y el verdor circundante, aunque no dejó de notar el estado de abandono en que se hallaban los cerca de 600 habitantes de Santo Domingo, una vez que la Laguna, tras la independencia de España, menguó notablemente su papel de vía comercial obligada entre Guatemala, Chiapas, Tabasco y Campeche. Apenas si la ganadería y el tabaco permitían sobrevivir a la población, que, como la carmelita, juzgó más bien indolente ("nada permite pensar que el genio de sus habitantes resucite en mucho tiempo la afortunada situación de antaño [...] carecen completamente del espíritu de iniciativa; son incapaces de salir de su apatía y de sus rutinas tradicionales a no ser que se les estimule por un impulso exterior").

Aunque había considerado superfluo dar una descripción de los monumentos de Palenque y sobre todo del edificio denominado "el palacio", puesto que ya varios otros lo habían hecho, ${ }^{27}$ no pudo sustraerse a especular acerca de la historia

${ }^{26}$ Que casi seguramente alude a ch'oles de Tumbalá, aunque no deja de ser curioso, de haber sido ése el caso, que apunte que pocos entendían su idioma, pues era de uso relativamente frecuente en la región.

${ }^{27}$ No obstante, describe la "galería", el arco falso maya y la torre cuadrangular del Palacio ("en pie en medio de la soledad, con toda la majestad de las cosas que han vivido mucho tiempo"), destacando que, "bajo zarzas, arbustos trepadores y árboles enormes", y "en un radio de considerable extensión" podían advertirse "vestigios que hasta ahora no se han explorado sino muy imperfectamente" (Morelet, 2015: 287). 
del sitio, considerando que "el pasado es un campo inagotable donde es lícito investigar, y echaré mano de este privilegio para aventurar algunas conjeturas sugeridas por el aspecto del lugar y por ciertas analogías históricas". Entre tales "conjeturas" destaca la de la intervención tolteca en los monumentos prehispánicos de Palenque y Yucatán, los cuales exhibían un carácter arquitectónico similar que respetaba "las mismas reglas de arte". Que los arquitectos de unos y otros compartían "hasta en los menores detalles, una conformidad de ideas, de gusto y de origen, cuya expresión ha podido variar según la época y la necesidad, sin perder su carácter primitivo y eminentemente nacional", lo mostraban, señala, "la estructura de los edificios, su base piramidal, la ausencia de bóvedas, la forma particular de los techos, la manera de cubrirlos, el uso del estuco y de la pintura en el decorado, los bajorrelieves esculpidos en el lugar, la semejanza de los símbolos jeroglíficos...". Puesto que Palenque se le antojaba mucho más antigua que Mayapán, apoyándose en datos del cronista Antonio de Herrera y Tordesillas, se atrevió a aventurar que la segunda había sido construida por emigrantes chiapanecos. Eso sí, alertó, de paso, sobre los peligros de comparaciones aventuradas con creaciones culturales lejanas:

El bajorrelieve conocido con el nombre de piedra de la cruz [el Tablero de la cruz] merece ser citado como uno de los mejor tratados [...], ha preocupado mucho tiempo a los sabios con su enigma; su imaginación ha creído reconocer alternativamente, entre los objetos representados, los símbolos del culto de Menfis y los de la religión cristiana, pero es prudente, a la espera de que un nuevo Champollion nos dé la clave de los jeroglíficos americanos, ver en él sólo una alegoría indígena inspirada en las producciones del clima (Morelet, 2015: 293).

De sus notas sobre el sitio podría colegirse que lo que más llamó su atención fue el "misterio impenetrable" que lo envolvía, y el mensaje que se desprendía de su abatido esplendor: "un ejemplo palpable de la vacuidad de la humanidad. Nos encontramos frente a frente con aquellos antiguos personajes cuyos simulacros han sobrevivido sin poder asignarles una edad, sin conocer su origen, su pasado, ni lo que ha sido de ellos". Y por si la destrucción operada por la naturaleza no fuese suficiente, el lugar tenía que enfrentar el vandalismo provocado por viajeros, coleccionistas, e incluso por los vecinos, pues cada primavera se transformaba "en un lugar de recreo donde los ociosos de Santo Domingo vienen en familia, causando graves deterioros a los monumentos, que conservan la huella imborrable de su paso. Suspenden sus hamacas a la sombra de los majestuosos árboles, se mecen indolentemente gracias al murmullo de los arroyos y saborean un marisco abundante en ese lugar". ${ }^{28}$

\footnotetext{
${ }^{28}$ Aclara que se trata de una "especie de melanoide [levísima], cuya carne es análoga a la de nuestros caracoles", de la cual gustaban mucho los indios, y que obtenían golpeando, mientras caminaban, "dos de esas conchas, la una contra la otra, con tanta fuerza y precisión [que] a pesar de su dureza termina rompiéndose una de las dos por su extremidad; después chupan la sustancia y pasan a la segunda...".
} 
¿Dónde están los bajorrelieves de estuco que estimularon la admiración de Dupaix? ¿Y aquellos grabados alegóricos, motivo de tantas disertaciones sabias? ¿Qué ha sido de aquellos medallones, adorno del peristilo del gran palacio? Unos han sido destruidos para siempre, otros han sido mutilados o arrancados de los muros; si existen algunos vestigios todavía, es a causa de las injurias del tiempo, gracias al cual se han preservado de las de los viajeros: es verdad que, para compensarnos, han inscrito su nombre en el lugar de aquellos viejos recuerdos (Morelet, 2015: 293-294).

Se trataba de "restos hermosos, sin duda, en su antigua rudeza", de los que emanaba "en medio de la soledad, cierta grandeza imponente", pero no era justificable "el entusiasmo de los arqueólogos". Exceptuando "las tablas simbólicas", cuyo grabado le pareció "muy correcto", lo demás exhibía defectos: "las líneas ornamentales adolecen de un exceso de rectitud; el dibujo, de excesiva simetría; la escultura, de un acabado deficiente $[\ldots \mathrm{y}]$ en cuanto a las figuras, revelan en su ejecución bárbara, los primeros pasos de un arte en el inicio de su desarrollo". No en balde las calificó como "groseras esculturas americanas, cuyo único mérito es su origen misterioso" (Figuras 13 y 14). ${ }^{29}$
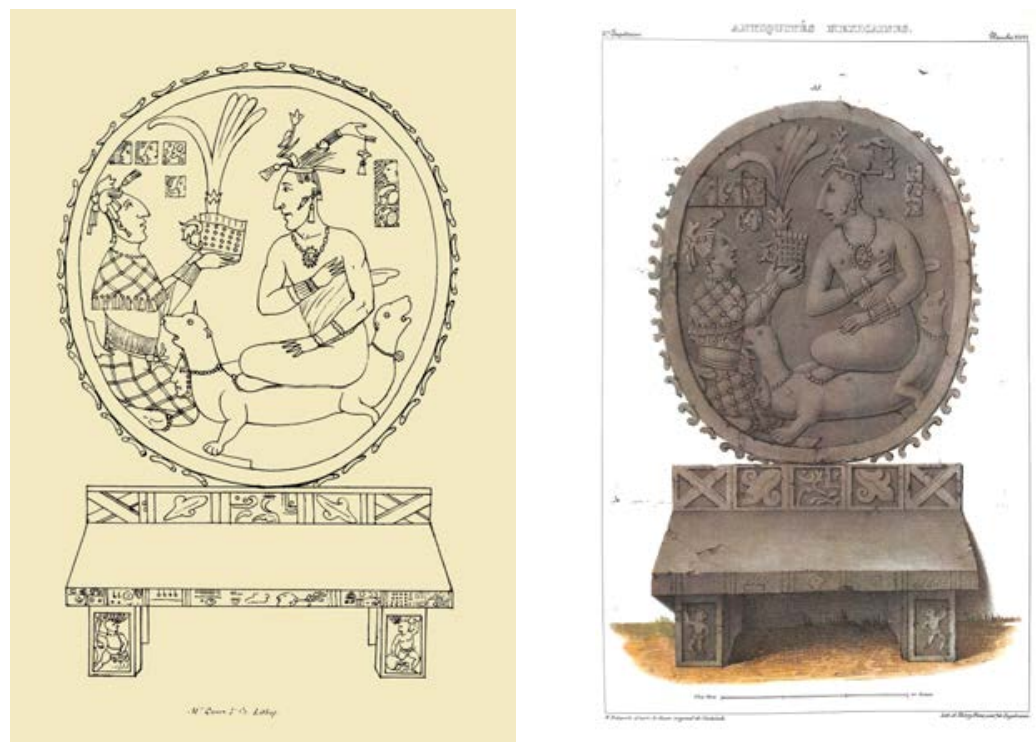

Figuras 13 y 14. Dos versiones del Tablero oval, uno de los "medallones" del Palacio de Palenque. Dibujo de Antonio del Río, 1787 (apud Romero, 2010) y dibujo de Dupaix, 1978).

Conjetura que la cal que se obtenía del molusco, "de excelente calidad", hubiese sido empleada "en la composición del estuco que revestía los edificios de la antigua ciudad" (Morelet, 2015: 301).

${ }^{29}$ Por ello, alertaba a sus lectores para que no cayeran en "un entusiasmo exagerado", y confesaba que, por su parte, "admiro los bajorrelieves de Palenque sobre las fachadas de sus viejos palacios; me interesan, me conmueven, y nutren mi imaginación; pero si se transportan al Louvre, resultan sólo esbozos amorfos capaces de dejarme frío e indiferente" (Morelet, 2015: 285). 
Opinión tan burda y lapidaria sorprende en particular cuando la vemos aparecer en un apartado donde se recuerda que los constructores del sitio no contaban con animales de carga ni útiles de hierro que hubiesen facilitado su labor, pero lo que más llama la atención es que habiendo señalado que habría que esperar por un Champollion que encontrase "la clave de los jeroglíficos americanos", y tras dedicar párrafos completos a la capacidad mostrada por los mayas en el arte de plasmar sus ideas a través de "jeroglíficos pintados e incluso de caracteres simbólicos consagrados a la expresión de las ideas" y habla de "verdaderos libros, donde se representaba el curso de las estaciones, los animales, las plantas útiles y la topografía de la región", así como su encomiable empeño por transmitir los conocimientos científicos y artísticos a través de escuelas, se anote que el palencano era "un pueblo ignorante del arte de descomponer los sonidos y reproducirlos por medio de la escritura". ¿O es que atribuía acaso tales logros a los mayas peninsulares y no a los de Palenque? ¿O a los mismísimos toltecas? De hecho, apunta:

[...] Si se considera la analogía incontestable existente entre los antiguos monumentos de México y las ruinas de Palenque, y entre éstas y las de Yucatán; la posición geográfica de estos restos escalonados en el camino de la emigración tolteca y revestidos de un carácter de antiguiedad tanto más pronunciado cuanto menos distantes se hallan de su punto de partida, se llegará a la conclusión de que aquellos diferentes trabajos fueron la obra de un mismo pueblo que sucesivamente fundó Tula, Mitla, Palenque, Mayapán y todos los edificios hoy en ruinas de la Península (Morelet, 2015: 292). ${ }^{30}$

Mucho más amables parecen haber sido los recuerdos que le dejó el entorno natural, incluyendo aquél al que los derruidos edificios servían de marco. Vayan dos muestras:

Al salir el sol, los colibríes y pájaros moscas zumbaban alrededor de las lianas que cubrían los muros del antiguo palacio; las libélulas, de color púrpura o esmeralda, pasaban con vuelo rápido y caprichoso; nubes de mosquitos subían en columnas cerradas de la espesura de la selva; el pájaro carpintero hacía resonar los troncos de los árboles; todo se despertaba en el bosque: era un canto grandioso y continuo (Morelet, 2015: 294).

$\mathrm{Al}$ anochecer aquel edificio antiguo se transformaba en un palacio encantado, y comprendo el terror supersticioso de los indígenas, quienes se niegan a pasar allí la noche. Están convencidos de que en aquellos lugares habitan los espíritus

30 Termina el párrafo asentando una franca elucubración: "Por lo demás, la raza tolteca no se ha extinguido en Guatemala, donde constituye en la región montañosa una población trabajadora, emprendedora y orgullosa, capaz de jactarse de su antiguo origen" (ibid.). 
antiguos, los bajorrelieves cobran vida a la luz de la luna y los guerreros descienden de sus cuadros de piedra y recorren las sombrías galerías... Por mi parte, sin temer a aquellos visitantes nocturnos, no podía evitar sentir cierta emoción: en primer lugar flotaba en la atmósfera una multitud de luces aladas, unas veces con el brillo de una chispa y otras como un resplandor fugitivo perdido en polvaredas luminosas; al mismo tiempo, salían voces indefinibles de todos los puntos del bosque $[\ldots]$ eran suaves como cantos de aves y misteriosos como una lengua desconocida. En torno a mí veía la vida por todas partes; era como si las plantas, los árboles y los muros viejos se animaran y hablaran su lenguaje (Morelet, 2015: 294-295).

Abandonó el lugar después de 15 días que, aseguró, “difícilmente se borrarán de mi memoria... Cazábamos, tendíamos trampas a los animales salvajes, recogíamos plantas, conchas y mariposas, cuyas variedades eran infinitas, sin cansarnos de admirar aquella espléndida naturaleza y de vagar a través de aquellas ruinas con un secreto guardado", mientras su acompañante, Morin, se afanaba por atrapar cocuyos para llevar a Francia, persuadido de que "los ojos fosforescentes de aquellos insectos brillarían eternamente con la misma intensidad”. Tuvo incluso oportunidad de oír el canto particularmente melódico de un ave que, a decir de los indios, "vive en solitario alrededor de las ruinas, sin que jamás, según sus tradiciones, la haya observado nadie en otra parte". Tampoco él pudo verla, pese a haberse internado en la selva persiguiéndola. Nunca más volvió a escucharla "y hasta olvidé la tradición que había recogido acerca de ella en las orillas del Usumacinta”.

\section{Del oriente tabasqueño}

Camino hacia el Petén guatemalteco, ${ }^{31}$ Morelet recorrió la hoy conocida como Región de Los Ríos, describiendo con detalle, curiosidad científica y su siempre envidiable pluma los paisajes y sus habitantes; imágenes que además plasmó en dibujos.

Para esta última etapa de su viaje por tierras mexicanas optó por regresar por la misma vía, permaneciendo una semana en la hacienda San Jerónimo, donde completó sus notas sobre la explotación irracional del palo de Campeche, caracterizada por "la ignorancia y negligencia" ya que los propietarios no tenían orden alguno para la tala; se limitaban a dar carta blanca a los leñadores, los cuales "se desparraman por el bosque, escogen y derriban a la buena de Dios; su único impulso es su capricho y su única regla su comodidad”. No le escapa que los indígenas, sin cuyo auxilio "sería imposible sacar partido de los bosques",

\footnotetext{
31 Acerca de esta parte del periplo, consúltese el estudio introductorio de Taracena en el tomo I de la nueva edición de Morelet (Taracena, 2015).
} 
no tenían muchas otras posibilidades, pues eran abusados en forma tal que "no podría vituperarse bastante".

Los obreros, cuyos brazos emplea [el "especulador"], dependen casi siempre de él; se establecen en el lugar de la explotación, con sus mujeres e hijos, cuando están casados; se les entrega una choza y un hacha, y enseguida se les vende todo lo necesario para subsistir, porque la hacienda generalmente se encuentra a una distancia considerable de los mercados. ¿Se creerá que la venta al por menor de los suministros comprados al por mayor y con rebaja, producen a menudo el mayor beneficio del negocio de la tala? El balance de este vergonzoso tráfico se eleva a veces entre el $150 \%$ y el $300 \%$ en favor del vendedor, en función de su rapacidad o la de sus agentes. Un pobre leñador con una deuda de 50 piastras, deberá 100 al finalizar el primer año, y perderá al cabo del segundo la esperanza de librarse algún día de la deuda. Nadie en el país, el cual puede llamarse con justicia un país de iniquidad, tiene escrúpulos para enriquecerse de esta manera; es decir, robando a unos obreros desdichados una parte de su subsistencia diaria (Morelet, 2015: 310). ${ }^{32}$

Por lo que toca a la naturaleza, es claro que si Morelet pensó agotada su capacidad de asombro ante la corriente del Palizada, erró sus cálculos. Aún faltaba el espectáculo incomparable del Río de Monos, el Ozomantli: "Exceptuando la primera impresión producida en mí por el Nuevo Mundo, debo confesar que las escenas del Usumacinta, por su melancólica grandeza y su poesía primitiva, son las que me han dejado recuerdos más profundos".

Nahuyacas, monos aulladores, tortugas hicoteas, pejelagartos, cascabeles, jaguares, caimanes [...] y, al salir el sol, "el canto de las aves [...], una mezcla de todas las lenguas, una confusión inaudita de sonidos extraños y discordantes". $\mathrm{Al}$ acercarse el cayuco en que navegaba a las riberas del río o sus afluentes, los monos pardos trepan por las ramas, los tapires interrumpen su sueño para huir rompiendo las cañas, de las ramas se desprenden lagartos que caen en el cieno; iguanas verdes, azules, violadas y parduzcas, trepan por las márgenes y desaparecen en los agujeros; sólo el zopilote rey "hermosa ave de plumas negras y blancas, cuya cabeza y cuello resplandecen, en la época del cortejo, con los más admirables colores" permanece imperturbable en lo alto de una ceiba completamente seca "por la vejez", mientras eclosionan los enormes ramos rosados de las flores del jolocín (Figura 15).

\footnotetext{
32 No fue el único viajero que hizo comentarios acerca de la difícil vida de los peones. De hecho casi todos los extranjeros que visitaron el sur del país se refirieron al tema, entre ellos el botánico austriaco Carl Bartholomaeus Heller, quien llegó a México también en 1847, y a más de describir con detalle la vegetación de la sierra tabasqueña, expuso las terribles condiciones en que laboraban los zoques serranos, los cuales, consideró, no disfrutaban "de mayor libertad que los esclavos de Luisiana o Las Antillas"; los hacendados, apuntó, "son tanto más ricos entre más pobres se hacen los indios a su servicio" (Heller, 1987: 535-536).
} 


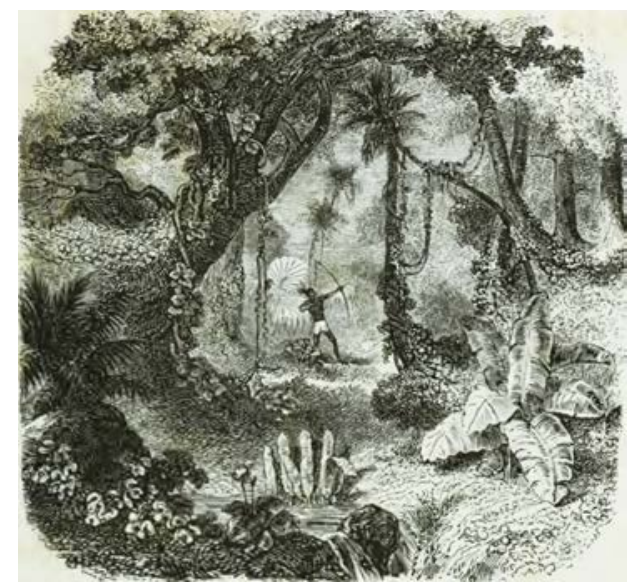

Figura 15. Sin título (Morelet, 2018: 1).

No pudo resistir el descender del cayuco e internarse en la selva:

Desde los primeros pasos creí hallarme en un mundo encantado: era aquello una profusión de palmeras, de vegetales extraños y monstruosos, de lianas retorcidas en un desorden inexplicable, de ramas seculares cargadas de plantas bulbosas, como jardines aéreos. En una palabra, un esplendor, una riqueza, una diversidad capaz de confundir la imaginación más exagerada. Toda aquella magnificencia se me apareció en un rayo de luz filtrado a través del follaje; más allá reinaba un crepúsculo no disipado por el sol. Ante aquel escenario extraordinario y perteneciente, en apariencia, a la primera edad del mundo, me detuve confundido, admirado, como quien, en una noche oscura, es deslumbrado repentinamente por un meteoro... (Morelet, 2015: 270-271).

Si la aparente "confusión" en la naturaleza se antojaba explicable, el desorden sociopolítico que afectaba por entonces a Tabasco, territorio al que lo condujo el Usumacinta, era a su vez harto más que comprensible. Zarandeado por las pugnas entre centralistas y federalistas, el estado había sufrido en 1830 la invasión de fuerzas militares campechanas, enviadas por Yucatán, que se pronunció por el centralismo y se sustrajo a la Federación. Tomado San Juan Bautista de Villahermosa, los federalistas trasladaron los poderes a Teapa. A partir de 1831 los gobiernos locales oscilaron en sus simpatías. Al año siguiente, nueva invasión campechana, que repelerían los tabasqueños en una memorable batalla librada en Acachapan el 25 de julio. Con la instalación de Manuel Buelta como gobernador los liberales recuperaron el poder, pero no por ello cesaron levantamientos, revueltas y represiones, a los que se sumaron hambrunas y una epidemia de cólera morbus que provocó la muerte de miles de tabasqueños.

Puesto que su ruta fue fluvial, nuestro autor no visitó más que dos de las poblaciones ubicadas en las cercanías del Usumacinta. Tenosique y Balancán, esta 
última habitada por 80 familias, entre ellas algunas de españoles que explotaban a los indios, bien empleando su fuerza de trabajo, bien "comerciando con algunas bagatelas que compran en la Palizada" y soñando "noche y día con la manera de obtener semejantes ventajas sin arriesgarse ni trabajar", mientras que "los indios, todavía más renuentes a las fatigas de la mente que a las del cuerpo, no toman parte alguna ni interés en sus especulaciones". Tenosique, "último punto habitado de Tabasco", contaba por su parte con un centenar de "cabañas". Allí, en el centro se ubicaban los descendientes de españoles, aumentando los pobladores indios conforme se avanzaba a las orillas, hasta quedar como "el elemento dominante y hasta único de la población”. La aldea no difería mayor cosa de otras ("son los mismos rasgos generales, la misma población, las mismas costumbres"), pero estaba rodeada "de inmensos bosques".

En ningún otro sitio del Nuevo Mundo, asentó, le había parecido la naturaleza "tan ardiente y tan vigorosa" como en esas húmedas llanuras, pero la prodigalidad de los suelos ("tierra dotada de un vigor y una juventud eternos") que producían "sin interrupción y casi sin esfuerzos, azúcar, café, tabaco, especias, en una palabra todo lo esperado de su fertilidad por el cultivador", cobraba también un alto precio: arbustos y árboles destilaban "jugos acres y cáusticos”; los caimanes infestaban ríos y lagos; los insectos venenosos pululaban a la par de los más peligrosos reptiles. Era ilusorio esperar "gozar de la frescura de las aguas y de la sombra de la selva"; la especie humana se veía forzada a defenderse "sin tregua ni descanso" de un enemigo que estaba por todas partes; "la avispa, la araña, la hormiga, hasta los escorpiones de agua, inofensivos en nuestras ciénagas, se encuentran allí dotados de aguijones y mandíbulas impresionantes”. Incluso la llegada de las lluvias, que moderaban el ardor de la temperatura, traía consigo miasmas deletéreos que exhalaban de los lugares húmedos y suspendían "en la atmósfera sus gérmenes destructores”. Y tampoco los animales, domésticos o salvajes, las tenían todas consigo; unos y otros eran "atacados en cierta época del año por himenópteros, los cuales depositan sus huevos en los tejidos; al salir las larvas se enfurecen; una picazón dolorosa les irrita y exaspera; se desgarran frotándose contra los árboles y las llagas inflamadas degeneran en úlceras incurables y hasta mortales por la malignidad del clima".

A mediados de mayo, festividad de san Isidro, el naturalista había sabido de un nuevo ataque, esta vez a sus oídos, a causa de los tres días y tres noches que los vecinos dedicaron a celebrar al santo labrador madrileño, con una procesión (“que coincidió milagrosamente con el regreso de las lluvias"), las campanas tañendo a rebato, y la música de tambores y pífanos. ${ }^{33}$ El escándalo, al que se sumaba la barahúnda de los borrachos, era tal, apunta, que hasta el cura optó por

\footnotetext{
33 Pocos años antes, 1834, el barón de Waldeck había calificado como "infernal” la música que acompañaba la procesión de la imagen del venerado Señor de Esquipulas en San Juan Bautista de Villahermosa. El escándalo era tal, que agregó que desearía una audición semejante: "por castigo a mis más crueles enemigos" (apud Cabrera, 1987: 310-311).
} 
huir el pueblo, dejando a un anciano indio en su lugar, el cual, "si no ofició [misa], poco faltó para ello". Hasta su puerta llegaron los músicos, que "mendigaban" en las casas "subsidios" de alcohol. Se deshizo pronto de ellos al no tener para ofrecerles, "más que un cocimiento de ruibarbo". ${ }^{34}$

Tras concierto tan poco armónico, continuó su viaje por el Usumacinta. A poco de atravesar la garganta donde el río inicia su recorrido por las llanuras aluviales, toparon con un cayuco manejado por un lacandón o "caribe", al que hizo atrapar. La información obtenida del cautivo le dio pie para redactar algunos párrafos sobre los "débiles restos" de esa "nacionalidad india", "pobres salvajes inofensivos, y de carácter pacífico que sólo piden a los españoles alguna tolerancia en su último refugio", ubicado en las cordilleras cercanas a Tenosique.

En ocasiones, los más atrevidos se aventuran hacia el recinto de las poblaciones limítrofes, con el fin de conseguir en trueque los objetos necesarios para su consumo; aunque en general evitan el comercio con los blancos; observan sus movimientos desde las alturas y se ocultan a sus miradas. Armados de arcos y flechas, como en los tiempos primitivos, todavía les llena de espanto la detonación de un arma de fuego. Viven como vivían sus padres, en la poligamia y el politeísmo; cada mujer, cuando tienen varias, disfruta de vivienda distinta y de un campo para satisfacer sus necesidades [...] (Morelet, 2015: 333). ${ }^{35}$

El naturalista también interrogó a su "prisionero" (como él lo llama) sobre la existencia de sitios arqueológicos en el área, cosa que éste negó (temiendo acaso que aceptarlo acarrease visitantes indeseables). Y es que el francés estaba convencido que en esa "soledad cubierta de bosques" que caracterizaba a "las fronteras indeterminadas" de Tabasco y de Guatemala, habían de encontrarse vestigios de "la fértil provincia de Acalan" y las ruinas de aquella ciudad que despertó la admiración de Hernán Cortés, Itzamcanak, famosa por su comercio, que se extendía hasta los últimos límites de la América Central (Figuras 16 y 17). ${ }^{36}$ Comerciantes, entre los cuales, asegura nuestro autor, se elegía como señor al más hábil.

\footnotetext{
${ }^{34}$ A diferencia de todo lo demás aquí consignado, que figura en el tomo I de la obra, esta experiencia es narrada en el tomo II, editado en 2018 (46-47).

35 Que esos descendientes de yucatecos (asentados en partes del área selvática donde hasta el siglo xVIII vivieron los choltí lacandones, y a quienes se atribuyó erróneamente el mismo gentilicio), practicasen la poligamia y el politeísmo de que dan cuenta incluso trabajos etnográficos posteriores es creíble, pero resulta muy difícil pensar que se espantasen con las armas de fuego, que conocían desde centurias atrás.

${ }^{36}$ No andaba muy errado. El sitio arqueológico de El Tigre, que se ha identificado como el Itzamkanac prehispánico y de inicios de la época colonial, se ubica en la porción del Alto Candelaria, en el sur del actual Campeche, que antes formaba parte del estado de Tabasco.
} 

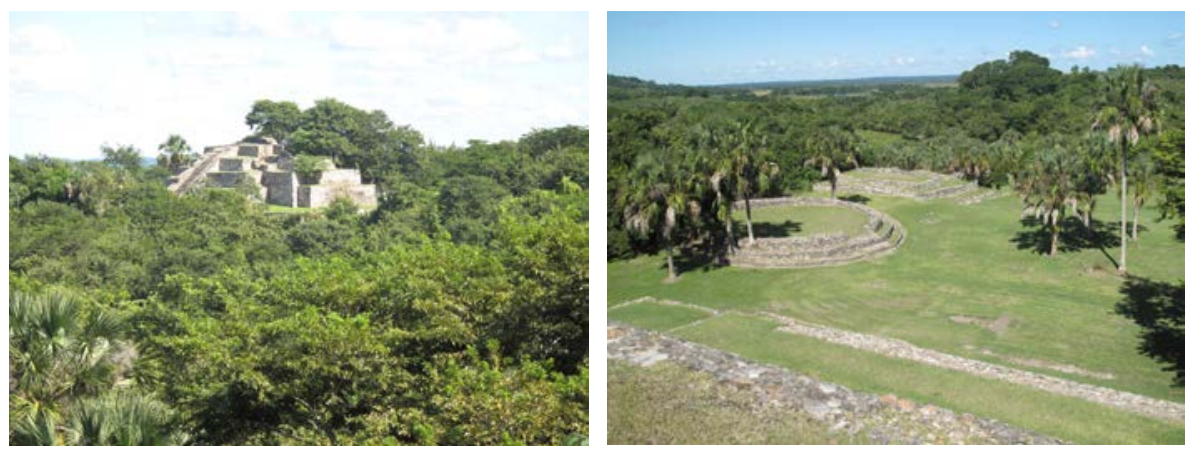

Figuras 16 y 17. Itzamcanak, Campeche (“El Tigre”)

(Fotografías de Mario Humberto Ruz, 2012).

Canceladas las posibilidades de seguir interrogando al cautivo, ya que escapó durante la noche, Morelet volvió a lo suyo. Enfocó su atención en los peces del río y las lagunas adyacentes, destacando al "pez lagarto" y cinco especies de tortugas de agua dulce, entre ellas la hicotea, cuya carne, que comparó con la del pollo, le pareció "aventaja en delicadeza a la de las tortugas marinas. A cambio de éstas y otras muchas delicias de que proveía el río (hoy, por cierto, casi desaparecidas), los pobladores de la comarca habían de lidiar con mosquitos, ratas, lagartos, murciélagos, alacranes, "cucarachas enormes, hormigas y varias especies de arañas horribles”, a más de culebras tan temibles como la cascabel y la nahuyaca, que incluso aprovechaba la vegetación de las márgenes para saltar a las embarcaciones. Por si fuera poco, los jaguares se presentaban con frecuencia en los alrededores de las moradas; los caimanes se arrastraban para sorprender en las tinieblas a perros y aves, y los reptiles venenosos se deslizaban hasta las habitaciones.

\section{Más allá de la descripción}

Sin lugar a dudas la principal riqueza del texto de Morelet radica en las detalladas descripciones que dedica a la naturaleza de los espacios transitados; descripciones botánicas y zoológicas cuya valía se acrecienta por el hecho de que dan cuenta de un paisaje ahora en no pocos sentidos histórico, debido a la acción humana que ha convertido a esas riberas y selvas bajas, medianas y altas, en meros pastizales, producto tanto de la despiadada explotación de maderas preciosas, tintales y manglares, como a desarticulados programas que propiciaron una tala brutal para favorecer una ganadería de dudosos beneficios en vez de alentar la vocación silvícola de esos suelos.

No obstante lo anterior, en la obra es posible apreciar continuas y valiosas referencias acerca de la cotidianidad de los habitantes de esas regiones, antes marcadamente indígenas aunque para entonces se consolidaban ya varias de ellas 
como bastiones mestizos, incluyendo referencias a la difícil relación que se estableció entre las comunidades mayas y los gobiernos decimonónicos (bien nacionales, bien regionales). ${ }^{37}$

Un aspecto de interés es el hecho de que el naturalista ancle a menudo sus reflexiones en consideraciones de tipo histórico, por lo general las registradas a partir de la conquista, aunque en ciertos casos va más allá y alude al devenir prehispánico. Si bien en algún párrafo apunta que se trataba de hechos "desconocidos", resulta claro que se basó para ello, en fuentes que acaso resultasen novedosas para un naturalista pero que no lo serían tanto para un humanista europeo de la época. Alude, así, a las obras de conquistadores como Bernal Díaz del Castillo y Hernán Cortés, cronistas como Herrera, Villagutierre y Soto-Mayor, y López Cogolludo o historiadores como Clavigero, aunque cabe recordar que puesto que Voyage dans l'Amérique Centrale... salió a la luz en 1857, nuestro autor no pudo beneficiarse de la Relación de Diego de Landa, publicada por primera vez por Brasseur de Bourbourg, aunque incompleta, siete años más tarde. ${ }^{38}$

Con independencia de la mayor o menor novedad de las fuentes empleadas y la manera en que la subjetividad de su formación decimonónica tiñe el esquema narrativo, son de destacar su capacidad de síntesis y el cuidado en la exposición cronológica (aunque en ocasiones confunde a tal o cual personaje histórico, como le sucede en el caso de los Montejo), y sus apuntes de tipo comparativo, apreciables por ejemplo cuando equipara las civilizaciones desarrolladas en el Anáhuac con la de Yucatán, las cuales, considera, tenían los mismos avances en las artes mecánicas, con la misma imperfección en los medios; leyes civiles perfectamente análogas, bajo una constitución política diferente, y el mismo culto, "ensangrentado por el sacrificio de víctimas humanas", aunque puntualizando:

No obstante, las costumbres de los mayas eran menos sanguinarias en comparación con las de sus vecinos; sólo con el paso del tiempo se impregnaron, por decirlo así, de la barbarie de los aztecas, pero conservando siempre alguna cosa de su primitiva dulzura. Las mujeres, por ejemplo, no asistían a las ejecuciones capitales, y la función de sacrificador, importante en Anáhuac, no gozaba de ninguna estima en Yucatán. La antropofagia, esa odiosa superstición, que deshonraba el estado social de los mexicanos, se practicaba sólo de manera accidental; pero existía sin duda, pese a la negación de [López] Cogolludo, quien refutaba con insistencia la aventura de Valdivia y sus compañeros [...] Pero ninguno de estos escritores nos hace asistir al espectáculo de las hecatombes humanas capaces de afligir con un duelo perpetuo al imperio de Moctezuma (Morelet, 2015: 222-223).

Puesto que considera que ambos procesos civilizatorios procedían de un origen común, no le resulta extraño que compartiesen rasgos en lo que a registros

\footnotetext{
37 Traté tal aspecto en el estudio introductorio a mi cargo en la nueva edición de la obra de Morelet (Ruz, 2015b), por lo que no me entretengo aquí en ello.

38 Acerca de las ediciones de este texto de Landa, que en varios sentidos revolucionó el conocimiento sobre los mayas, véase la introducción de María del Carmen León a la edición de 2003: 52-59.
} 
del tiempo o sistemas de escritura compete, si bien hace hincapié en el hecho de que los mayas, a base de ejercicios de memoria, mantuviesen con peculiar cuidado conocimientos y tradiciones gracias a sus libros y el destacado papel que cumplían para ello sus escuelas, trasmisoras de ciencias y artes. Y se pregunta qué papel jugaron en ello los toltecas "quienes parecen haber determinado la emancipación intelectual de Anáhuac", o el producto de una civilización más antigua, perteneciente a una raza de aborígenes absorbida por las migraciones extranjeras, como parecería derivarse de "la esfera limitada en la cual se movían los dos pueblos cuando fue descubierto su país".

Sus apreciaciones acerca de la organización social propia de esos pueblos son ciertamente discutibles a la luz de los conocimientos actuales, y su manera de mezclar rasgos propios de sistemas monárquicos, feudales y hasta algunos próximos al despotismo oriental, le hace caer en planteamientos confusos, que le dan pie para abonar la hipótesis (entonces en boga), de un pueblo maya pacífico, de algún modo "contaminado" por el belicismo mexica. Apunta así, por ejemplo:

[...] la benignidad de los mayas antes de la alteración de sus costumbres por el contacto con los aztecas, sus virtudes hospitalarias, su consideración hacia los mayores y su veneración de $[\mathrm{sic}]$ los muertos atestiguan un profundo respeto por las leyes de la moral y una percepción bastante clara de sus principios. La creencia en la inmortalidad del alma y en una justa repartición de recompensas y castigos, la costumbre de confesarse públicamente en las enfermedades y en los grandes peligros, y una ceremonia [el caputzihill] notable por su analogía con el bautismo, ceremonia [que se] observaba únicamente en Yucatán y cuyo objeto era purificar al niño de toda mancha moral y disponerlo hacia el bien, bastan para rehabilitar a una raza condenada injustamente por la política, el interés y los prejuicios obstinados (Morelet, 2015: 227).

A lo anterior, aduce, se sumó la despiadada sumisión que tuvieron que sufrir bajo el poder español y el "fanatismo religioso", que terminaron por "oscurecer" la inteligencia indígena. Y a ello se agregaba lo que califica de "veneno que ha contribuido quizá más poderosamente que la guerra y la esclavitud, a la destrucción de la raza indígena": el alcoholismo, que "domina al indio de un extremo al otro de América, bajo los trópicos como hacia el polo, con una energía capaz de superar todas las otras inclinaciones"; y contra la cual poco podría hacerse a menos que el Gobierno interviniese de forma enérgica, como hizo el tabasqueño al prohibir la venta de alcohol. Agregaría, páginas adelante, que "la influencia de esa política contribuyó a la aniquilación de la raza americana más que las violencias de la conquista y el celo ciego de las órdenes religiosas, las cuales, para combatir la idolatría, destruyeron los monumentos y la historia del país".

Ciertamente, reconoce, el Gobierno español intentó poner freno a los excesos, pero las leyes, que no se cumplían,

[...] llevaban la impronta del prejuicio fatal, el cual estigmatizaba a los indios, y contribuyeron a ahondar el abismo que separa todavía hoy a los vencedores de los vencidos. Todos los privilegios concedidos a éstos eran testimonio de su inferiori- 
dad: asimilados con menores de edad en materia civil, exentos del servicio militar, pero obligados a un trabajo forzado, sometidos además a un tributo y a humillantes castigos, formaban en el Estado una clase sin nombre, sin porvenir y pronto sin pasado, comparable a los ilotas de Esparta (Morelet, 2015: 229).

Pese a todo, opina, España trató de manera más humana a los naturales que los ingleses que invadieron porciones más norteñas de América, los cuales "por su frío egoísmo y sus despiadados cálculos, han merecido con justicia la reprobación de la posteridad", pues éstos no se preocuparon ni de proteger ni de gobernar o educar a los naturales:

[...] su único objetivo fue el de apropiarse del suelo y expulsar de él a los antiguos amos conforme fuesen avanzando. Algunas veces aquellas usurpaciones fueron disfrazadas de transacciones ilusorias cuyo móvil era el hambre y cuyo precio era el veneno [del alcohol]. Fue así como grandes provincias no costaron a sus poseedores sino sólo una bagatela insignificante (Morelet, 2015: 232).

Y otro tanto, aunque en menor proporción, podría reprocharse a los franceses colonizadores.

La independencia de las distintas metrópolis halló a los nativos en situaciones diversas, pero procedió con todos ellos con casi el mismo inhumano desapego. Cierto, la Confederación de la Unión buscó guardar las formas y puso en marcha diversos programas, y hasta hubo "hombres generosos quienes de vez en cuando han alzado la voz en favor de los indios", retomando "en menor escala, la obra realizada por los españoles hace tres siglos [...] pero las frías teorías y los esfuerzos mezquinos no resucitarán a un pueblo inexistente; tanto menos cuanto que la circunspección política del gobierno americano no le permite avanzar sino con una extrema reserva en esta vía tardía de reparación", pese a los "colores novelescos" con que "la imaginación de un escritor nacional” revestía la existencia "precaria y miserable" que caracterizaba a "los remanentes de la familia india, desterrada hacia los límites extremos del territorio...".

Las colonias independizadas de España, por su parte, no encontraron más que esclavos cuando lo que requerían era ciudadanos, pues dada su "rara perseverancia en los hábitos y las costumbres", los nativos "se mostraron rebeldes al impulso que se trató de comunicarles”, según trató de mostrar en un largo párrafo que bien vale la pena citar completo:

Al grito de libertad resonando de un extremo a otro de América y con la euforia del primer éxito, cayeron las cadenas, se eliminaron las castas, se abolieron los privilegios, mientras los derechos del hombre, proclamados por la Revolución francesa, se volvieron la base de un nuevo edificio social, compuesto por los elementos más heterogéneos. Así fue como los indios llegaron al nivel de sus antiguos amos y gozaron de una independencia desconocida para sus antepasados hasta bajo la dominación de los caciques; hombres ignorantes, embrutecidos y degradados por una larga servidumbre fueron honrados con el título de ciudadanos, y la ley fun- 
damental del Estado los conminó a ejercer sus derechos. Pero esta emancipación, para la cual no estaban preparados, ni por las lecciones ni por los ejemplos de sus padres, lejos de contribuir al beneficio del país, se convirtió en la fuente de un grave perjuicio. Incapaces de comprender y de apreciar una situación tan nueva, los indígenas sólo fueron sensibles a la relajación inmediata de sus lazos y a la exoneración de cualquier tipo de prestación y de tributo; ningún sentimiento generoso, ningún germen de emulación, ambición o progreso se reveló en ellos; librados de una tutela necesaria para ellos, se dejaron arrastrar sin medida a la pereza, a la ebriedad, y cuando fueron intimados a cumplir con sus obligaciones, rompieron el contrato resistiéndose abiertamente o regresando a la vida de la selva. Fue así como se vieron decaer aldeas populosas y florecientes bajo la administración colonial; los cultivos disminuyeron, escasearon los alimentos y los albergues sostenidos por la previsión del gobierno para los viajeros cayeron en ruinas por todas partes; las vías públicas se degradaron, ya no se iba a la escuela, y terminó estallando una guerra civil, sin que la nueva legislación contase con los recursos necesarios para restablecer el antiguo equilibrio (Morelet, 2015: 230-231).

Hondo caló en el indio la experiencia: "Acostumbrado desde hace mucho al desprecio o a la compasión, se considera como un ser de una especie inferior, para rehabilitarlo ante sus propios ojos sería necesaria una sucesión de esfuerzos tan perseverantes como prolongada ha sido la servidumbre". Esperar otro tipo de cosecha, acotó, sería una "extraña ilusión", puesto que no se había preparado el terreno para ninguna especie de cultivo.

Para dar fe de la actualidad de su razonamiento, citó en su apoyo un texto de la Gaceta de Guatemala de apenas el año anterior, 1846: "El desprecio del cual son objeto viene de la opinión. Declarad tanto como queráis que el indio tiene un alma razonable, el español lo oye y no lo contradice; pero en su fuero interno guarda su convicción y la transmite a su hijo, si no por las palabras, al menos por sus actos y su ejemplo". ${ }^{39}$

La situación en Yucatán le merece comentarios particulares, comenzando por el escaso número de "españoles" (una duodécima parte de las 546350 personas que contabilizó el censo oficial publicado en 1846), y continuando con la baja estima en que se tenía a los mayas, cuyas facultades intelectuales se consideraban inferiores a las de los afrodescendientes, pese a que el estado se mantenía gracias al trabajo indígena, pues el comercio -en manos primordialmente no indias - enfrentaba numerosas dificultades, pese a la buena situación peninsular en el contexto del Golfo, dadas las características de su mar poco profundo y poblado de arrecifes, y la ausencia de puertos, exceptuando Laguna de Términos y el río Usumacinta, pero la primera "admite únicamente barcos de pequeño porte", y el segundo "riega sólo una pequeña parte del territorio".

A ello se agrega la concentración poblacional, que desde la conquista, había privilegiado la vertiente del "Mediterráneo mexicano" como si, no obstante la inferioridad del suelo, "debiera esperar de allí su fortuna y su porvenir", siendo que

${ }^{39}$ Morelet, 2015: 229, nota al pie 187. 
los mejores terrenos se localizan en las áreas de aluvión de Campeche y Tabasco (que califica como "el Delta de Yucatán"), entrecortadas por ríos y pantanos, donde crecen las mejores especies maderables. El norte, en cambio, es territorio muy seco, y si bien los indígenas habían sabido aprovechar la estructura cavernosa del suelo para recoger y conservar las aguas pluviales que desaparecían completamente de la superficie, mientras que esas grandes cavidades llamadas cenotes, proveían a las necesidades de la población durante los periodos de sequía, como el de Bolonchén (que es de suponer conoció por la ilustración de Catherwood, cuya obra cita), los españoles, en cambio, "a lo largo de tres siglos, no han fundado en el país algo capaz de rivalizar con aquellas obras de utilidad pública” (Figura 18).

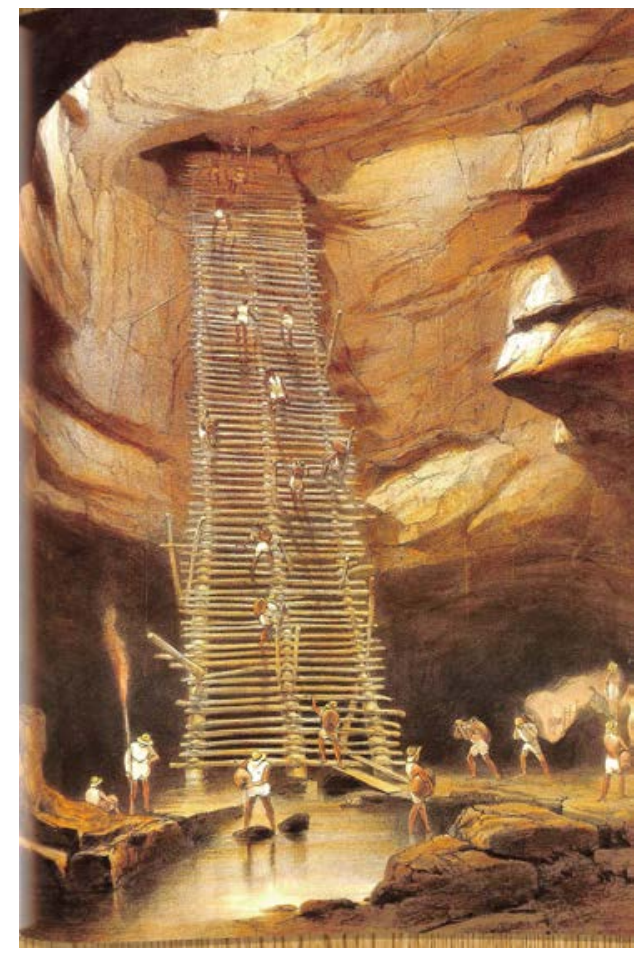

Figura 18. El cenote de Xtacumbilxunán, Bolonchén, Campeche (Catherwood, 1840).

A su parecer, Yucatán era una "pequeña república oligárquica, cuya aristocracia se componía de labradores y comerciantes. ${ }^{40}$ Más o menos desvinculada del pac-

${ }^{40}$ En un anexo se preocuparía por detallar los principales productos objeto de comercio en la Península: "Reses vacunas, caballos, mulas, ovejas, cerdos, carne de vaca salada [itasajo?], cueros, sebo, aceite de pescado, cera, miel, cochinilla, lana hilada, escamas [sic] de tortuga, maíz, arroz, azúcar en bruto, melaza, ron, tabaco en hojas y en cigarros, cáñamo crudo, algodón, añil, vainilla, zarzaparrilla, aceite de ricino, chile de Tabasco, arruruz, resinas odoríferas, bija [achiote], goma de copal, madera 
to federal $[\ldots]$ seguía una política independiente y obedecía sólo a su propio impulso", y cuyo comercio se encontraba principalmente en manos de los españoles nacidos en Europa, junto a los cuales "languidecen los criollos sobre los restos de su antigua opulencia”. Allí, como en casi toda la América española, advierte que

[...] una antipatía, por decirlo así, tradicional, divide a las dos clases de ciudadanos, una de las cuales hereda poco a poco las riquezas y dignidades de la otra; observan con envidia al extranjero que ejerce su industria en el país; el buen éxito de sus operaciones les causa un secreto disgusto, y el beneficio que le reportan les parece un perjuicio para sus propios intereses y hasta para sus derechos legítimos (Morelet, 2015: 208).

No debe creerse que el naturalista achacase el origen de todos los problemas locales a los no indios, parte de ellos se vinculaban con el aislamiento en que vivía buena parte del componente maya, ${ }^{41}$ al que resultaba "muy difícil hacerle cambiar su independencia por la perspectiva de una mejor suerte, pues los beneficios de la civilización no le parecerán una compensación suficiente de las obligaciones y restricciones que aquella le impone", mientras que manteniéndose en relativo aislamiento, podía preservarse gracias a contar con los elementos y las actitudes necesarias para la autosubsistencia:

[...] transporta y utiliza los materiales para su choza; cultiva o recolecta en los bosques los vegetales para su alimentación; su mobiliario y su ropa son también obra de sus manos; la experiencia heredada de sus padres le enseña a suplir las necesidades de la salud y de la enfermedad, y a sacar partido de los variados recursos ofrecidos por la naturaleza salvaje. Esos conocimientos le bastan, y de ningún modo aspira a ampliarlos (Morelet, 2015: 233).

De particular interés se antojan ciertas consideraciones que alguien podría tachar hoy de "psicologistas" pero que para esa época no dejan de parecer novedosas, y que aluden a otros factores del "carácter" indígena que, a decir de Morelet, influían también en el desdén, cuando no franco rechazo, por sumarse a las aparentes ventajas de la modernidad.

Nos habla así, por ejemplo, del presentismo propio del indio ("poco preocupado por el pasado y el porvenir, el tiempo no tiene valor para él"), su escasa ambición ("considera el reposo de los sentidos y del espíritu como la suprema dicha"), y el fatalismo y la resignación, que a decir del naturalista heredó de su religión antigua, pues su conversión al cristianismo se le antoja más aparente que sólida, y reducida. Un cristianismo limitado, "hoy como en el pasado, al abandono ostensible de su idolatría", la asistencia a los oficios o el recurrir a los sacramentos

para construcción, para ebanistería y para tinte, hilos y cuerdas de agave, sombreros de pecíolos de palma, hamacas, guitarras, sal, piedra caliza, mármoles, ocres, piedras moleñas [es decir, para moler; metates] y pedernales" (Morelet, 2015: 350).

${ }^{41}$ De hecho, al abordar los datos estadísticos de 1846 apuntó existir "30 o 40000 nómadas, que se escapan al censo y se libran del impuesto". 
"cuando la iglesia no está lejos"; meras "demostraciones exteriores, suficientes a los fervorosos misioneros", pero muy lejanas de los verdaderos valores del cristianismo. "Paganismo exteriormente cristianizado", asentaría en otra parte.

Alude también a la frugalidad de los indígenas, que los españoles comparaban "con un ayuno rígido y perpetuo", pero que, a su parecer, "no es sino una virtud negativa, nacida de la necesidad y dispuesta a sucumbir en cuanto lo permitan las circunstancias", y dedica algunas reflexiones al hábito maya del ahorro, rayano en la avaricia ${ }^{42}$ pero, no deja de reconocer que "es probo y su pundonor le lleva a cumplir fielmente con sus compromisos hacia el hombre encargado de pagarle, y a quien llama 'amo'. En el desempeño de su actividad jamás se le podrá reprochar nada, siempre y cuando no pruebe el licor".

Responsable de la pervivencia de tales actitudes y costumbres es la educación que recibe en casa, tanto de parte de la madre, que arrulla al niño con "mil supersticiones pueriles con las cuales ella misma fue amamantada, e imprime a su joven inteligencia el sello de su propia credulidad" en seres invisibles y poderosos que moran en las selvas y las ruinas o en espíritus invisibles, "encantadores, vagando por el campo bajo el aspecto de bestias salvajes". Le induce a confiar en los amuletos y a desconfiar de los blancos, y

[...] le comunica al mismo tiempo una sumisión pasiva cuya fuente en la conciencia de su superioridad. Todo hace pensar que también inculca en la joven inteligencia de su hijo algunos rasgos de las antiguas tradiciones; murmura a su oído nombres [que se creen] olvidados. Nada ha podido borrar del espíritu de los indígenas el recuerdo ultrajante de la conquista; han perdido el hilo de los acontecimientos, pero conservan la memoria de la anterioridad de sus derechos (Morelet, 2015: 234-235).

Mientras que el padre, tras entregarle un machete y un bulto ligero para que comience a acompañarlo, apenas cumpla 10 o 12 años,

[...] le enseña a orientarse en la selva y a reconocer el camino mediante los más pequeños indicios, a prevenir con un gran sentido de la observación el ataque de reptiles venenosos, a recolectar la miel de las abejas salvajes, a manejar un remo si el río está cerca; le muestra las lianas con la propiedad de adormecer a los peces, aquellas útiles por su flexibilidad o que ofrecen agua al viajero sediento; el lecce [sic] María, bálsamo precioso para la cura de las heridas; ${ }^{43}$ el guaco, con hojas de un verde purpúreo, capaz de neutralizar la mordedura de las serpientes; lo conduce a los lugares apartados donde crece el cacao, etc. Es así como el niño se acostumbra

42 "Ninguna privación le parece demasiado pesada para conservar su economía, ninguna seducción lo hace titubear; vive miserablemente al lado de su tesoro, y muchas veces se lleva a la tumba el secreto de un depósito desconocido por sus hijos [que lo] ignoraban", y es tal avaricia la que le hace preferir desempeñar un trabajo pesado que pagar "un impuesto ligero" (Morelet, 2015: 236-237).

${ }^{43}$ Se refiere al árbol leche maría (Calophyllum brasiliense Cambess), también llamado en México barí, barillo, cedro cimarrón o santa María, entre otros varios nombres. A más de su excelente madera, muy apreciada por carpinteros y ebanistas, su látex, conocido como "Bálsamo María", es empleado para afecciones cutáneas, al igual que el aceite que se obtiene de su semilla. 
a sacar provecho de sus propios recursos y como inicia una vida de independencia y de aventura, experiencias transformadas más tarde en influencia irresistible (ibid.).

Dotado con tales enseñanzas, y perfectamente entrenado para hacer una milpa o construir una vivienda, un joven maya es capaz de mantener a una familia ya desde los 17 años, por lo que es común que comience a buscar pareja. Acota también que en ocasiones se les compromete desde la infancia, pero, dato de interés, insiste en que no es tan creíble el supuesto, muy difundido por entonces, de que el varón no se preocupe de la edad, los rasgos físicos o las cualidades de la que será su compañera. Cierto, quizá "la pasión del amor" no comporte "el sentido moral" que los europeos le atribuyen, "pero la atracción, cuyo germen es universal, no deja de producir sus efectos también aquí, cuando el varón se deshace en atenciones inusuales y la jovencita despliega sus inocentes coqueterías". Ésos, acota, son "síntomas" que sólo están ausentes "en los pueblos demasiado primitivos, donde se honra exclusivamente la fuerza física, y donde la mujer ocupa un lugar ínfimo y menos despreciado en la sociedad", y ni los antiguos peninsulares ni los habitantes del altiplano mexicano caían en esa categoría, como bien se deduce de la lectura de los cronistas.

Acaso alguien pueda alegar que "el amor de la patria y las virtudes cívicas" no están presentes, pero lo que ocurre es que "fueron sustituidos, en esta raza desheredada, por un sentimiento único, más profundo, el de la familia”. Ello explica el intenso apego que muestran por sus hogares:

[...] su choza es un asilo donde goza, rodeado de los suyos, de una autoridad indiscutible, compensatoria del desprecio y la superioridad de los blancos. Ahí, nada perturba su seguridad, nada contradice sus gustos, nada molesta sus hábitos: la sumisión y la devoción de su compañera son absolutas; sus hijos lo respetan y lo escuchan con docilidad; él mismo les da cariño, sobre todo en su temprana edad, cuida de ellos y los atiende hasta la época en la que los lazos mutuos se debilitan por la emancipación (Morelet, 2015: 236) (Figura 19).

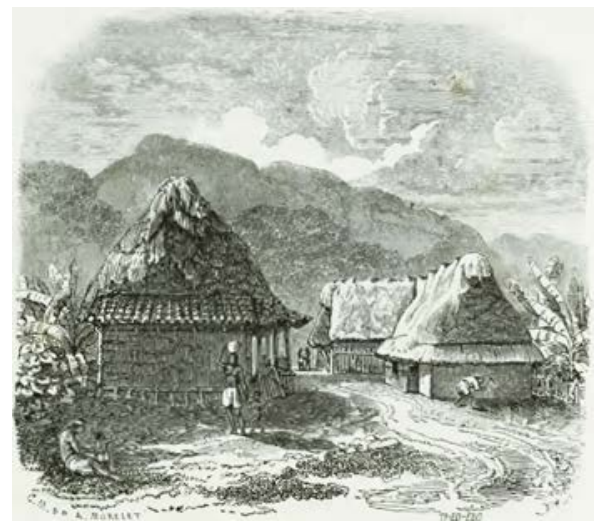

Figura 19. Sin título. Morelet, 2015: 176. 
Siglos de "larga y dolorosa" servidumbre, que —apunta certero— no inició con la llegada de los europeos sino que se experimentaba ya con los señores prehispánicos, le ayudan a explicarse la taciturnidad de ciertos indígenas,,$^{44} \mathrm{su}$ habitual mansedumbre y el mutismo frente a los blancos, nacidos de la desconfianza que le produce el trato con los otros, y que observó se mantenía pese a la igualdad que propugnaba la Constitución en vigor.

Por ello, asienta, "nunca se le escucha hablar de sus hijos, de su familia, de sus intereses más íntimos. No discutirá con usted, aunque sea muy obstinado con sus ideas, más bien formulará su opinión con una prudente reserva, o la pondrá en armonía con la de su interlocutor. Por ello no es difícil dejar en evidencia sus contradicciones, sin llegar, no obstante, a penetrar el secreto guardado". Pero no le escapa que su relación con otros indígenas es muy distinta:

[...] el sueño de su inteligencia les aporta un beneficio, desconocen el aburrimiento; se les ve, ociosos y silenciosos, soportar el peso de las horas con una increíble facilidad, pero si aparece de improviso un compañero, se animarán y desplegarán una locuacidad singular [...] Era para mí una causa de asombro siempre nueva, cuando viajaba con guías indígenas, el flujo de palabras intercambiadas entre sí con risas inmoderadas, durante una parte de la noche. Yo hubiese dado mucho por conocer el sentido de aquellas charlas, para poder juzgar el carácter divertido de su espíritu; pero al ignorar su lengua y no tener ningunas ganas de aprenderla, no disfruté de esa satisfacción (Morelet, 2015: 237).

Tomando en cuenta sus señalamientos acerca de la probidad indígena, así como los párrafos que dedica a la atención y cuidado que los mayas ponen en sus milpas, llama la atención el que refiera que su "holgazanería y la imprevisión" habían motivado al gobierno yucateco a ordenar a los alcaldes vigilar que los vecinos de sus pueblos sembrasen al menos 60 mecates de maíz por año, ${ }^{45} \mathrm{im}$ poniendo multas a quienes no lo hicieran, u obligándolos incluso a trabajar con un patrón o cumpliendo labores públicas forzadas (v. g. en los caminos), pero el francés se vale de ese argumento para retornar al tema de la explotación de la mano de obra indígena, lacerante ya desde la Colonia. ${ }^{46}$

Cualquier hombre de color con una deuda impagable se ve obligado a saldarla con su trabajo y se convierte hasta el reembolso en esclavo de su acreedor, quien recupera el valor de los préstamos efectuados con los servicios recibidos; incluso tiene derecho a venderlo o a ponerlo en alquiler. La única mitigación concedida por la ley al deudor es la de poder cambiar de amo cuando está descontento, siempre y cuan-

\footnotetext{
${ }^{44}$ Aunque, como mencioné antes, en algún pasaje apunta que eran alegres y no "sombríos y taciturnos, como nos pintan a los de la América del Norte..." (Morelet, 2015: 187).

${ }^{45}$ El mecate, medida empleada aún hoy, remite a una extensión de 20 x 20 metros.

${ }^{46}$ No andaba muy alejado de la realidad. Basta con revisar el valioso texto de Gabriela Solís (2003), para darse cuenta de los niveles de explotación a que se vieron sometidos los mayas peninsulares a lo largo del dominio colonial.
} 
do pueda encontrar a otra persona dispuesta a saldar su débito. El nuevo amo no desaprovecha la oportunidad para comprometer al indio con nuevas obligaciones, las cuales se agregan sucesivamente a la cuenta de los años anteriores y terminan haciendo imposible su liberación. Es así como una raza imprevisora, al trabajar en función de sus necesidades diarias, cede fácilmente al atractivo del crédito, cae en una trampa tendida a su ingenuidad y se encuentra fatalmente reducida a una servidumbre perpetua (Morelet, 2015: 238).

Se detiene en señalar la miseria en que, debido a estas condiciones vivía buena parte de la población indígena (al menos 4/5 partes de ella en localidades como Palizada y otras de "el bajo Tabasco"), a diferencia de los "industriales" que se enriquecían con la explotación de las selvas, y el impacto negativo que ello tiene en "el sentimiento de familia, principal virtud de esta raza", ya que los jóvenes enganchados para trabajar en las monterías solían renunciar al matrimonio para no arrastrar a una compañera a tan "triste destino", y "libres de cualquier vínculo o afecto, continúan escamoteando su porvenir y terminan aficionándose a una existencia vagabunda que favorece el trastorno de sus costumbres".

Tal explotación y "trastorno" no se le antojaban ajenos a la situación de guerra "de exterminio" que vivía Yucatán, y expresa su temor de que tanto Tabasco y Chiapas (como el vecino Guatemala) vean repetirse en algún momento escenarios similares. Actores particularmente responsables de ello serían, en su opinión, la escasa atención que se ponía a la "educación liberal” de las nuevas generaciones, el clero, "ávido y disoluto”, y sobre todo las altas autoridades mexicanas, enfrascadas en interminables disputas entre las facciones políticas y continuas violaciones al orden constitucional.

La reflexión con que el autor cierra el tomo resulta de lastimosa actualidad:

Todos tratan de tomar el mando del poder, por fraude o violentamente, para usarlo desvergonzadamente en provecho de sus intereses; las pasiones rivales libran una lucha constante, se suceden las revoluciones, el vínculo social siempre está a punto de romperse sin producir la indignación ni el asombro siquiera de una población, pervertida desde hace mucho tiempo, frente a tan deplorables excesos. En una palabra, los ciudadanos honrados pierden toda esperanza, en silencio, acerca del futuro de su país, pues el espíritu de desorden y la improbidad pública se encuentran tan arraigados que el mal les parece irremediable (Morelet, 2015: 339).

Dejándonos con reflexión tan turbadora acerca de la situación en México, Morelet abandonó el país para adentrarse en Guatemala. 


\section{Bibliografía}

Aramoni Calderón, Dolores

1991 "Los indios constructores de Palenque y Toniná en un documento del s. xvIII", Estudios de Cultura Maya, XVIII: 417-424. DOI: https://doi.org/10.19130/ iifl.ecm.1991.18.183.

Ballesteros Gaibrois, Manuel

1960 Nuevas noticias sobre Palenque en un manuscrito del siglo XVIII. México: Universidad Nacional Autónoma de México.

Baudez, Claude-François

1993 Jean-Frédéric Waldeck, peintre. Le premier explorateur des ruines mayas. Paris: Hazan.

Cabrera Bernat, Ciprián Aurelio (ed.)

1987 Viajeros en Tabasco. Textos. Villahermosa: Gobierno del Estado de Tabasco.

Catherwood, Frederick

1840 Views of Ancient Monuments in Central America, Chiapas and Yucatan. London: Owen Jones, Published by F. Catherwood.

Dixon Le Plongeon, Alice

2001 Aquí y allá en Yucatán. Traducción de Stella Mastrangello. México: Consejo Nacional para la Cultura y las Artes (Colección Mirada Viajera).

Dupaix, Guillaume Joseph

1978 Atlas de las antigüedades mexicanas halladas en el curso de los tres viajes de la Real Expedición de Antigüedades de la Nueva España, emprendidos en 1805, 1806 y 1807. Introducción y notas de Roberto Villaseñor Espinosa, Prefacio de Miguel León-Portilla. México: San Ángel Ediciones.

Garza, Mercedes de la

1981 "Palenque ante los siglos xVIII y xIx", Estudios de Cultura Maya, XIII: 45-66. DOI: https://doi.org/10.19130/iifl.ecm.1981.13.534.

Gil y Sáenz, Manuel

1892 Historia de Tabasco, 2a. ed. (anotada por R. Becerra y J. C. Santa-Anna). San Juan Bautista [Villahermosa]: José Ma. Ábalos Editor.

Heller, Carl Bartholomaeus

1987 “Carl Bartholomaeus Heller (1824-1880)", Viajeros en Tabasco. Textos, pp. 495554, Ciprián Cabrera Bernat (ed.). Villahermosa: Gobierno del Estado de Tabasco (Biblioteca Básica Tabasqueña 15).

Landa, fray Diego de

2003 Relación de las cosas de Yucatán, María del Carmen León (ed.). México: Consejo Nacional para la Cultura y las Artes. 
Morelet, Arthur

1857 Voyage dans l'Amérique Centrale, l'île de Cuba et le Yucatan. Paris: Gide y J. Baudry, Libraires-Éditeurs.

1990 Viaje a América Central (Yucatán y Guatemala), prólogo de Jorge Luis Arriola. Guatemala: Academia de Geografía e Historia de Guatemala.

2015 Viaje a América Central, isla de Cuba y Yucatán, traducción de Antonio Casas y Abdiel Macías, edición de Carolina Depetris. Mérida: Universidad Nacional Autónoma de México, Centro Peninsular en Humanidades y Ciencias Sociales. Tomo I.

2018 Viaje a América Central, isla de Cuba y Yucatán, traducción de Antonio Casas y Abdiel Macías, edición de Carolina Depetris. Mérida: Universidad Nacional Autónoma de México, Centro Peninsular en Humanidades y Ciencias Sociales. Tomo II.

Romero Sandoval, Roberto

2010 "Una rara edición del Informe de Antonio del Río sobre las ruinas de Palenque”, Estudios Mesoamericanos, 8: 103-112.

Ruz, Mario Humberto

1997 "La primera edad del mundo. Campeche bajo la lente de Arthur Morelet", Entre Letras, 2 (25): 3-4. Campeche: Sociedad Artística y Literaria.

2011 "Carlota: el imperio de una mirada", Del mar y la tierra firme. Miradas viajeras sobre los horizontes peninsulares, pp. 167-197, Mario Humberto Ruz y Eréndira Peniche (coords.). Mérida: Universidad Nacional Autónoma de México, Centro Peninsular en Humanidades y Ciencias Sociales y Universidad Autónoma de Campeche.

2015a “'Con finas memorias...'. El epistolario de Crescencio Carrillo y Ancona”, Ideas, ideólogos e idearios en la construcción de la imagen peninsular, pp. 201236, Mario Humberto Ruz y Adam T. Sellen (coords.). México: Universidad Nacional Autónoma de México, Instituto de investigaciones Filológicas, Centro de Estudios Mayas y Secretaría de Educación del Gobierno de Yucatán, Centro Estatal de Capacitación, Investigación y Difusión Humanística de Yucatán.

2015b "Los mayas de México en la mirada de un naturalista francés", estudio introductorio a la edición de Arthur Morelet, Viaje a América Central, isla de Cuba y Yucatán, tomo I, pp. 35-56, Carolina Depetris (ed.). Mérida: Universidad Nacional Autónoma de México, Centro Peninsular en Humanidades y Ciencias Sociales.

Sellen, Adam T.

2010 "Los padres Camacho y su museo: dos puntos de luz en el Campeche del siglo xIx", Península, V: 53-73.

Solís Robleda, Gabriela

2003 Bajo el signo de la compulsión. El trabajo forzoso indígena en el sistema colonial yucateco. México: Centro de Investigación y Estudios Superiores en Antropología Social, M. Á. Porrúa, Instituto Nacional de Antropología e Historia e Instituto de Cultura de Yucatán. 
Taracena Arriola, Arturo

2015 "El mundo americano de Arthur Morelet", estudio introductorio a la edición de Arthur Morelet, Viaje a América Central, isla de Cuba y Yucatán, tomo I, pp. 5-34. Carolina Depetris (ed.). Mérida: Universidad Nacional Autónoma de México, Centro Peninsular en Humanidades y Ciencias Sociales.

Torras Conangla, Rosa

2012 La tierra firme de enfrente. La colonización campechana de la Región de Los Ríos (siglo XIX). Mérida: Universidad Nacional Autónoma de México, Centro Peninsular en Humanidades y Ciencias Sociales.

Torre, fray Tomás de la

1975 "Relación del viaje de Salamanca (España) a Ciudad Real (Chiapas)", Historia de la provincia de San Vicente de Chiapa y Guatemala, de la Orden de predicadores, Libros $1^{\circ}$ a $3^{\circ}$, pp. 271-362, por fray Francisco Ximénez, Carmelo Sáenz de Santa María (paleografía y notas). Guatemala: Sociedad de Geografía e Historia de Guatemala.

Waldeck, Jean Frédéric de

1996 Viaje pintoresco y arqueológico a la Provincia de Yucatán, 1834-1836. México: Consejo Nacional para la Cultura y las Artes.

Weckmann, Luis

1989 Carlota de Bélgica. Correspondencia y escritos sobre México en los archivos europeos (1861-1868). México: Editorial Porrúa S. A. (Biblioteca Porrúa, 95).

Ximénez, fray Francisco

1975 Historia de la provincia de San Vicente de Chiapa y Guatemala, de la Orden de predicadores, Libros $1^{\circ}$ a $3^{\circ}$, Carmelo Sáenz de Santa María (paleografía y notas). Guatemala: Sociedad de Geografía e Historia de Guatemala.

Mario Humberto Ruz. Mexicano. Médico cirujano por la unAm, maestro en Antropología Social por la Universidad Iberoamericana, México, y doctor en Etnología por la École des Hautes Études en Sciences Sociales de París. Adscrito al Centro de Estudios Mayas del Instituto de Investigaciones Filológicas de la unam. Sus líneas de investigación incluyen la historia y linguiística histórica de grupos mayances y la etnología de grupos contemporáneos (tojolabales, chontales, ixiles y mayas peninsulares, entre otros). Su proyecto actual de investigación se titula "En las orillas del mundo. Religión y heterodoxia en la Guatemala colonial”. Entre sus publicaciones más recientes como autor único se encuentran: Naturalezas peninsulares, visiones imperiales. Yucatán: "El niño mimado del Imperio", 1865, 'La estrella que alumbra el Imperio'. Carlota en la Península de Yucatán (1865)”, y Mohonyhovi Sanctissima Trinidad... Chiapa y su Cofradía de la Vera Cruz al mediar el siglo XVII. mhruzs@gmail.com 